\title{
WATER CHEMISTRY OF SHOAL CREEK AND WALLER CREEK, AUSTIN, TEXAS, AND POTENTIAL SOURCES OF NITRATE
}

By Patricia B. Ging, Roger W. Lee, and Steven R. Silva

U.S. GEOLOGICAL SURVEY

Water-Resources Investigations Report 96-4167

Prepared in cooperation with the CITY OF AUSTIN 


\section{U.S. DEPARTMENT OF THE INTERIOR BRUCE BABBITT, Secretary \\ U.S. GEOLOGICAL SURVEY \\ Gordon P. Eaton, Director}

Any use of trade, product, or firm names is for descriptive purposes only and does not imply endorsement by the U.S. Government.

For additional information write to:

District Chief

U.S. Geological Survey 8011 Cameron Rd.

Austin, TX 78754-3898
Copies of this report can be purchased from:

U.S. Geological Survey

Branch of Information Services

Box 25286

Denver, CO 80225-0286 


\section{CONTENTS}

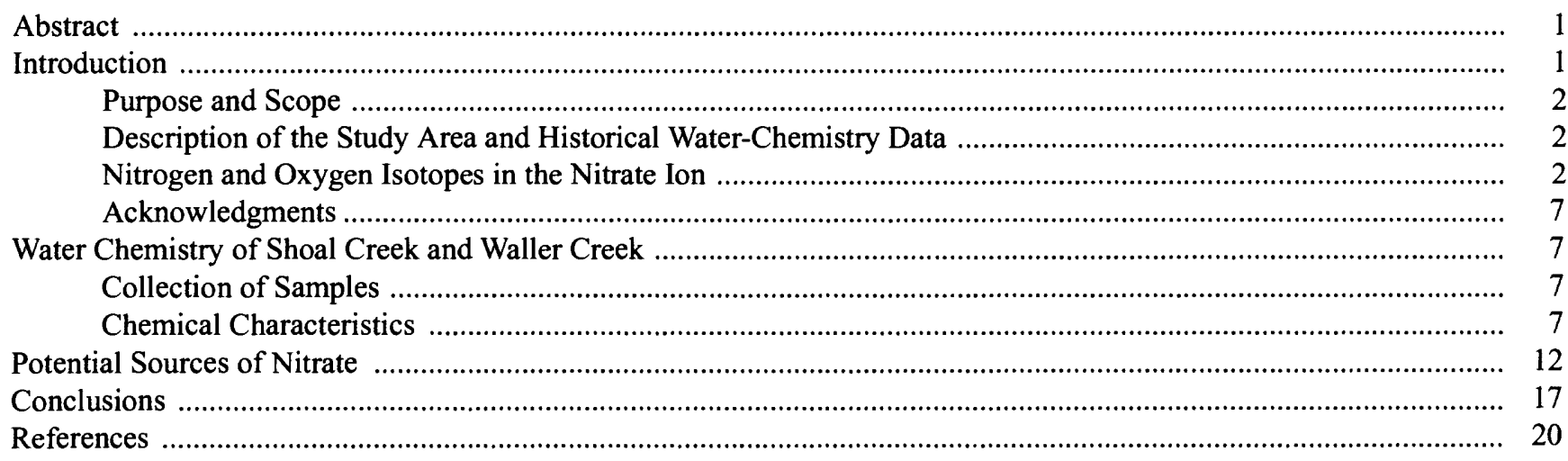

\section{FIGURES}

1-3. Maps showing:

1. Location of study area and sampling sites, Austin, Texas

2. Land use for Shoal Creek and Waller Creek watersheds, Austin, Texas ............................................ 4

3. Soils for Shoal Creek and Waller Creek watersheds, Austin, Texas ............................................... 5

4-8. Graphs showing:

4. Approximate compositional ranges of $\delta^{15} \mathrm{~N}$ and $\delta^{18} \mathrm{O}$ data for sources of nitrate

5. $\mathrm{pH}$ and alkalinity values grouped by sampling site for Shoal Creek and Waller Creek, Austin, Texas

6. Dissolved calcium, magnesium, and sodium concentrations grouped by sampling site for Shoal Creek and Waller Creek, Austin, Texas

7. Dissolved chloride, sulfate, and nitrogen concentrations grouped by sampling site for Shoal Creek and Waller Creek, Austin, Texas

17 20

8. Relations between sodium and chloride concentrations in stormflow and base flow for Shoal Creek and Waller Creek, Austin, Texas ...

9-10. Trilinear diagrams of water from:

9. Shoal Creek, Austin, Texas ......

10. Waller Creek, Austin, Texas

11-13. Graphs showing:

11. $\delta^{15} \mathrm{~N}$ and $\delta^{18} \mathrm{O}$ data for stormflow and base-flow samples from Shoal Creek and Waller Creek, Austin, Texas, relative to compositional ranges for sources of nitrate

12. $\delta^{15} \mathrm{~N}$ and $\delta^{18} \mathrm{O}$ averages by sampling date for all sampling sites in Shoal Creek and Waller Creek, Austin, Texas

13. $\delta^{15} \mathrm{~N}$ and $\delta^{18} \mathrm{O}$ data for all sampling sites in Shoal Creek and Waller Creek, Austin, Texas, and ellipses having radii of 2 standard deviations from averages of stormflow and base-flow samples

\section{TABLES}

1. Chemical data and isotope ratios for stormflow samples from Shoal Creek and Waller Creek, Austin, Texas

2. Chemical data and isotope ratios for base-flow samples from Shoal Creek and Waller Creek, Austin, Texas

3. Selected chemical data for rainfall samples taken near Shoal Creek and Waller Creek watersheds, Austin, Texas

4. Average nitrate concentrations, oxygen-18 values, and land-use information for stormfiow and baseflow samples from Waller Creek, Austin, Texas 


\section{Abbreviations and Acronyms}

cols./100 mL, colonies per 100 milliliters

$\mathrm{ft}$, foot

$\mathrm{mi}^{2}$, square mile

$\mathrm{mg} / \mathrm{L}$, milligram per liter

MCL, maximum contaminant level

MCC, Microelectronics and Computer Technology Corp.

USGS, U.S. Geological Survey

Per mil: A unit expressing the ratio of stable-isotopic abundances of an element in a sample to those of a standard material. Per mil units are equivalent to parts per thousand. Stable-isotopic ratios are computed as follows:

$$
\delta \mathrm{X}=\left(\frac{\mathrm{R}(\text { sample })}{\mathrm{R}(\mathrm{standard})}-1\right) \times 1000,
$$

where

$\mathrm{X}$ is the heavier stable isotope, and

$\mathrm{R}$ is the ratio of the heavier, less abundant stable isotope to the lighter stable isotope in a sample or standard.

The $\delta$ values for stable-isotopic ratios discussed in this report are referenced to the following standard materials:

Element $\quad \mathbf{R} \quad$ Standard identity and reference

$\begin{array}{ll}\text { oxygen } & \text { oxygen-18/oxygen-16 }\left(\delta^{18} \mathrm{O}\right) \\ \text { nitrogen } & \text { nitrogen-15/nitrogen-14 }\left(\delta^{15} \mathrm{~N}\right)\end{array}$
Vienna-Standard Mean Ocean Water (Fritz and Fontes, 1980, p. 11)

Standard atmospheric nitrogen, referenced to National Bureau of Standards, NBS-14 nitrogen gas (Fritz and Fontes, 1980, p. 16) 


\title{
Water Chemistry of Shoal Creek and Waller Creek, Austin, Texas, and Potential Sources of Nitrate
}

\author{
By Patricia B. Ging, Roger W. Lee, and Steven R. Silva
}

\section{Abstract}

Steep limestone slopes, thin soils, sparse vegetation, and impervious cover within the Shoal Creek and Waller Creek watersheds, Austin, Texas, contribute to rapid runoff that can quickly carry contaminants such as nitrate, into the creeks. Land use within the watershed is predominantly residential (single-family and multifamily dwellings). Impervious cover within both watersheds was about 55 percent during 1994-95.

Water samples were collected for chemical analysis at seven sites in the Shoal Creek and Waller Creek watersheds from September 1994 to April 1995. Samples were collected during 4 stormflow events and 3 base-flow periods. Water samples were analyzed for major ions and nutrients as well as for nitrogen and oxygen isotopes in the nitrate anion. Concentrations of dissolved constituents, including nitrate, are smaller in stormflow samples than in base-flow samples. Calculated dissolved solids range from 16 to 187 milligrams per liter for stormflow samples and from 213 to 499 milligrams per liter for base-flow samples.

Nitrogen and oxygen isotopes in dissolved nitrate in conjunction with water chemistry were used to indicate sources of nitrate in surface water. A combination of atmospheric nitrate, and soil nitrate and ammonium fertilizer is the most likely source of nitrate in stormflow samples (assuming that there is little or no use of synthetic nitrate fertilizers in the watersheds). Nitrogen and oxygen isotopic data in nitrate for stormflow samples are in or near the isotopic composition ranges for atmospheric nitrate, and soil nitrate and ammonium fertilizer sources. Nitrogen and oxygen isotopic data in nitrate for base-flow samples are in or near the isotopic composition ranges for soil nitrate and ammonium fertilizer, and sewage and animal waste sources of nitrate. Sewage is the most likely source of nitrate in base flow because of the potential for older sewer lines to leak, the proximity of sewer lines to creek beds, and an excess of chloride relative to sodium at some sampling sites (an indicator of the presence of sewage) under base-flow conditions. Nitrate in the creeks at any given time is a mixture that results predominantly from surface sources (atmospheric nitrate, soil nitrate and ammonium fertilizer) during stormflow and predominantly from subsurface sources (sewage) during base flow.

\section{INTRODUCTION}

Urban development can have an appreciable influence on water-quality conditions. Impervious cover in developed areas can result in increased runoff, conveying contaminants from point and nonpoint sources to local streams (City of Austin, 1990b). Any contaminant on land surface has the potential to quickly enter Shoal Creek and Waller Creek during storms owing to a large amount of impervious cover. Data previously collected by the U.S. Geological Survey (USGS) and the City of Austin have indicated the presence of nitrate, as nitrogen, in Shoal Creek and Waller Creek (Welborn and Veenhuis, 1987; City of Austin, 1990a); however, the data are inadequate to determine the sources of nitrate in the watersheds. Shoal Creek and Waller Creek drain into Town Lake, which is one of the water supplies for Austin. Increased nitrate concentrations in Town Lake could affect the quality of Austin's public water supply. Application of $\delta^{15} \mathrm{~N}$ and $\delta^{18} \mathrm{O}$ isotopic data from dissolved nitrate can indicate sources of nitrate in the Shoal Creek and Waller Creek watersheds and could contribute information useful for the improvement of water quality in these creeks. 


\section{Purpose and Scope}

The purpose of this report is to characterize the water chemistry in the Shoal Creek and Waller Creek watersheds and to indicate potential sources of nitrate in these watersheds. Twenty-five water samples were collected during stormflow conditions, and 14 water samples were collected during base-flow conditions at sites on the creeks or adjacent storm sewers from September 1994 to April 1995. Concentrations of selected constituents and isotopes of nitrogen and oxygen in the nitrate ion are used to show the water chemistry and potential sources of nitrate in the watersheds.

\section{Description of the Study Area and Historical Water-Chemistry Data}

The Shoal Creek and Waller Creek watersheds in the City of Austin (fig. 1) contain steep limestone slopes, thin soils, sparse vegetation, and impervious cover. The Shoal Creek watershed has a drainage area of approximately $13 \mathrm{mi}^{2}$. There is a $320-\mathrm{ft}$ decrease in altitude from the uppermost (highest elevations) part of the watershed to its outlet at Town Lake. The Shoal Creek watershed contains primarily residential areas with single-family dwellings (fig. 2). Soil type is predominantly "urban land" in the watershed (fig. 3) with about 55-percent impervious cover during 1994-95. The "urban land" soils classification represents soils altered and obscured by development that do not resemble soils described in the various series (U.S. Department of Agriculture, Soil Conservation Service, 1974).

The Waller Creek watershed has a drainage area of approximately $5.6 \mathrm{mi}^{2}$. As in the Shoal Creek watershed, altitude in the Waller Creek watershed decreases about $320 \mathrm{ft}$ from the uppermost part of the watershed to its outlet at Town Lake. The Waller Creek watershed consists primarily of residential areas with single-family and multifamily dwellings. Soil types were predominantly urban land in the Waller Creek watershed with about 55-percent impervious cover during 1994-95.

Both the Shoal Creek and Waller Creek watersheds contain wastewater lines for transport of sewage, but some septic tanks might exist in both watersheds (George Chang, City of Austin, oral commun., 1995). The exact location and condition of the septic tanks, if any, were not be determined during this investigation. One landfill located in the Waller Creek watershed con- tains drums filled with chemicals (George Chang, City of Austin, oral commun., 1995).

Historical water-chemistry data available for the Shoal Creek and Waller Creek watersheds were examined to determine variability of nitrate concentrations in the creeks. Although chemical data were collected as early as 1942, no consistent dataset of long-term water-quality monitoring was extant to determine temporal trends in water chemistry in the watersheds. The USGS collected water-chemistry data at six locations along Shoal Creek from 1942 to 1946 and from Shoal Creek at 12th Street (station 08156800) from January 1975 to present (1995). The USGS collected waterchemistry data from Waller Creek at 38th Street (station 08157000) from August 1954 to December 1962 and from Waller Creek at 23d Street (station 08157500) from October 1970 to August 1971. Dissolved nitrate concentrations (as nitrogen) generally ranged from 0 to $2 \mathrm{mg} / \mathrm{L}$ for both creeks (Raymond Slade, Jr., U.S. Geological Survey, oral commun., 1995) and were below the MCL of $10 \mathrm{mg} / \mathrm{L}$ for drinking water recommended by the U.S. Environmental Protection Agency (1996). City of Austin staff also have collected waterchemistry data at Shoal Creek at Woodhollow and at various locations along Waller Creek from 1992 to present. Dissolved nitrite plus nitrate concentrations (as $\mathrm{N}$ ) ranged from 0 to $2 \mathrm{mg} / \mathrm{L}$ and total nitrogen concentrations (as $\mathrm{N}$ ) ranged from 0 to $7.5 \mathrm{mg} / \mathrm{L}$, also below the recommended drinking-water standard (George Chang, City of Austin, oral commun., 1994).

\section{Nitrogen and Oxygen Isotopes in the Nitrate Ion}

The combined stable isotopic ratios ${ }^{15} \mathrm{~N} /{ }^{14} \mathrm{~N}$ $\left(\delta^{15} \mathrm{~N}\right.$ in per mil) and ${ }^{18} \mathrm{O} /{ }^{16} \mathrm{O}\left(\delta^{18} \mathrm{O}\right.$ in per mil $)$ in the nitrate ion, $\mathrm{NO}_{3}{ }^{-}$, can be useful in surface- and ground-water investigations to determine sources of nitrate. Nitrate in surface and ground water can be derived from one or more of the following sources: (1) microbial decay of organic matter in soils, (2) animal waste and sewage, (3) synthetic fertilizers, and (4) rainfall. The usefulness of $\delta^{15} \mathrm{~N}$ alone in identifying these sources is limited by overlapping ranges of $\delta^{15} \mathrm{~N}$ values and by changes in the $\delta^{15} \mathrm{~N}$ values of the sources caused by microbial denitrification and other processes. However, by combining $\delta^{15} \mathrm{~N}$ and $\delta^{18} \mathrm{O}$ analyses, identifiable separations for all sources of nitrate except ammonium fertilizers and bacterially produced soil nitrate are possible (Carol Kendall, 

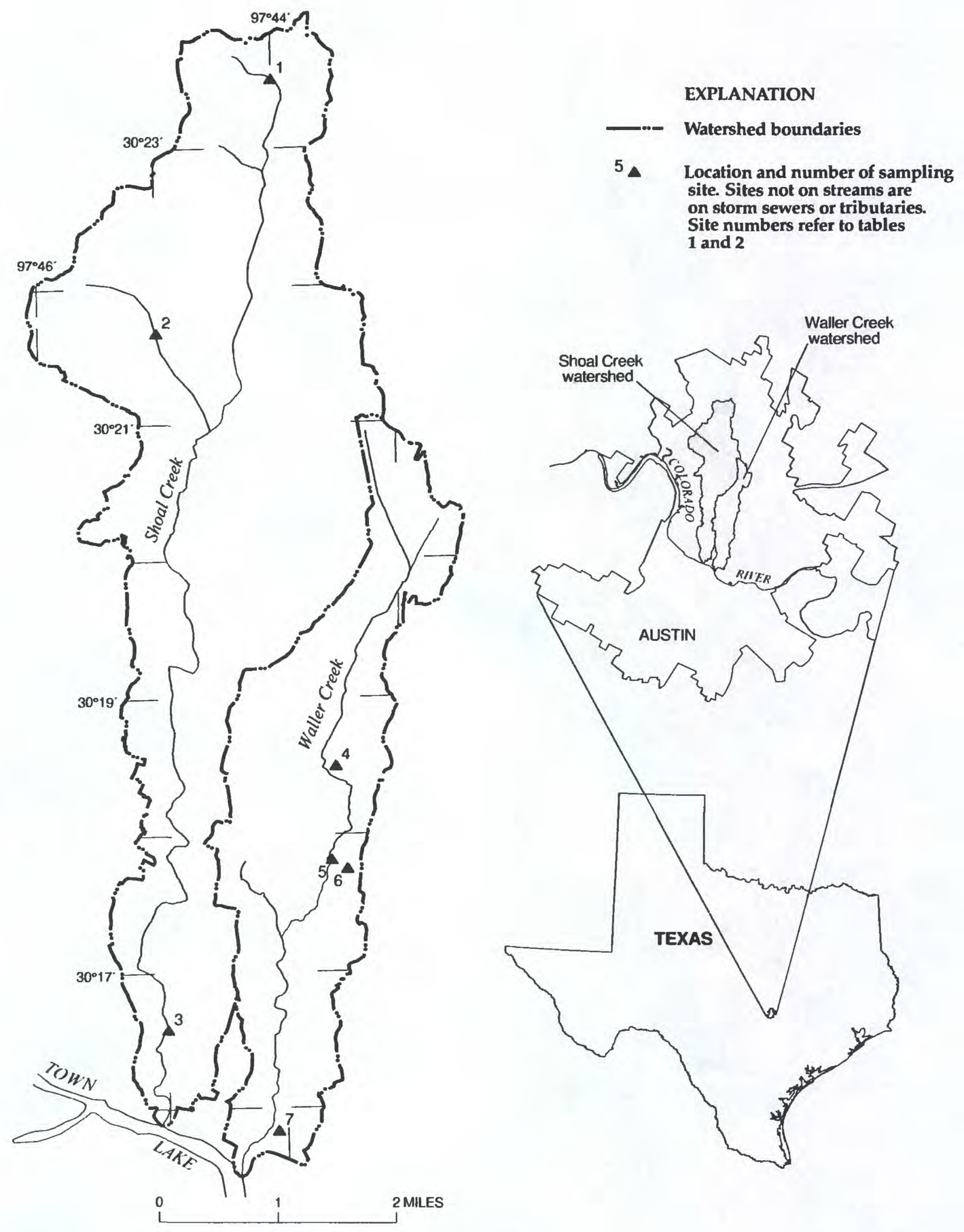

Figure 1. Location of study area and sampling sites, Austin, Texas. 


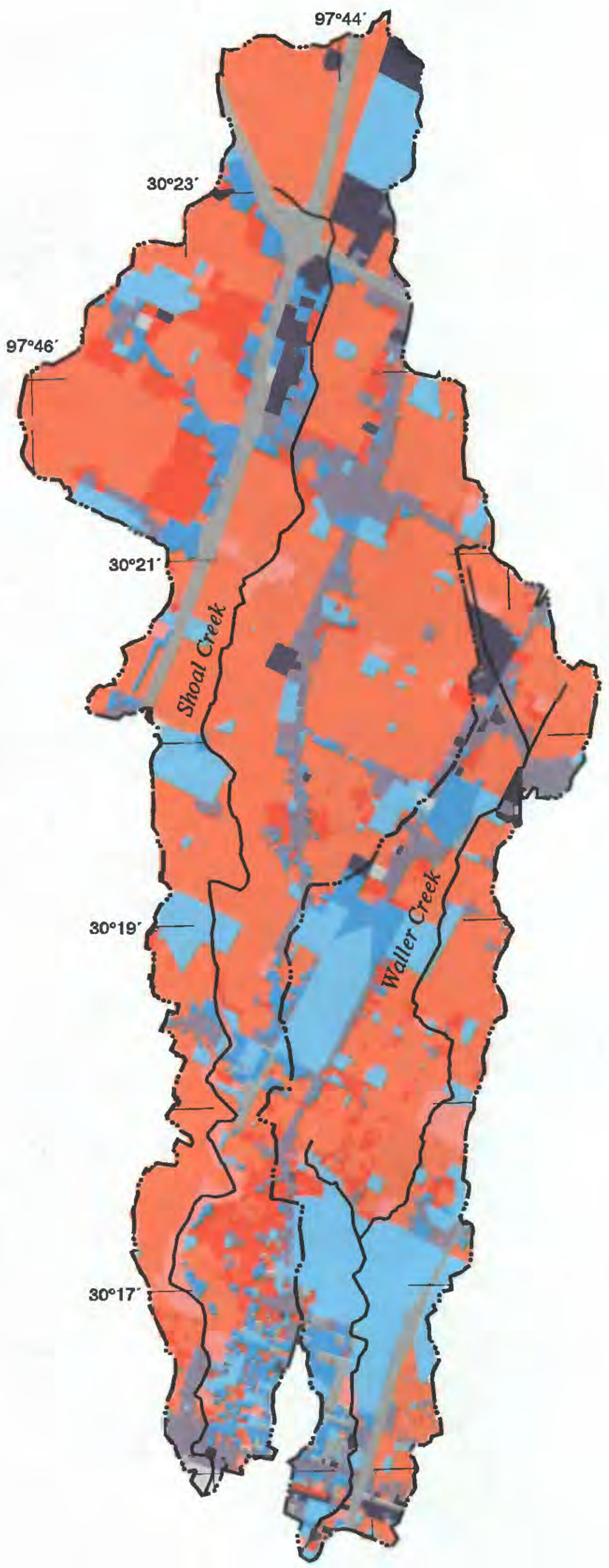

EXPLANATION

Single-family residential

Multifamily residential

Commercial

Office buildings

Industrial

Civic buildings

Open space

Transportation

Utilities

Undeveloped

Water

Watershed boundaries

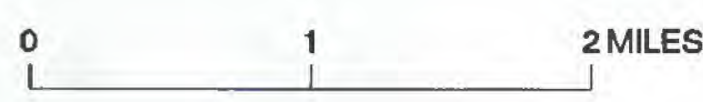

Figure 2. Land use for Shoal Creek and Waller Creek watersheds, Austin, Texas (Fatima Paiva, City of Austin, written commun., 1995). 

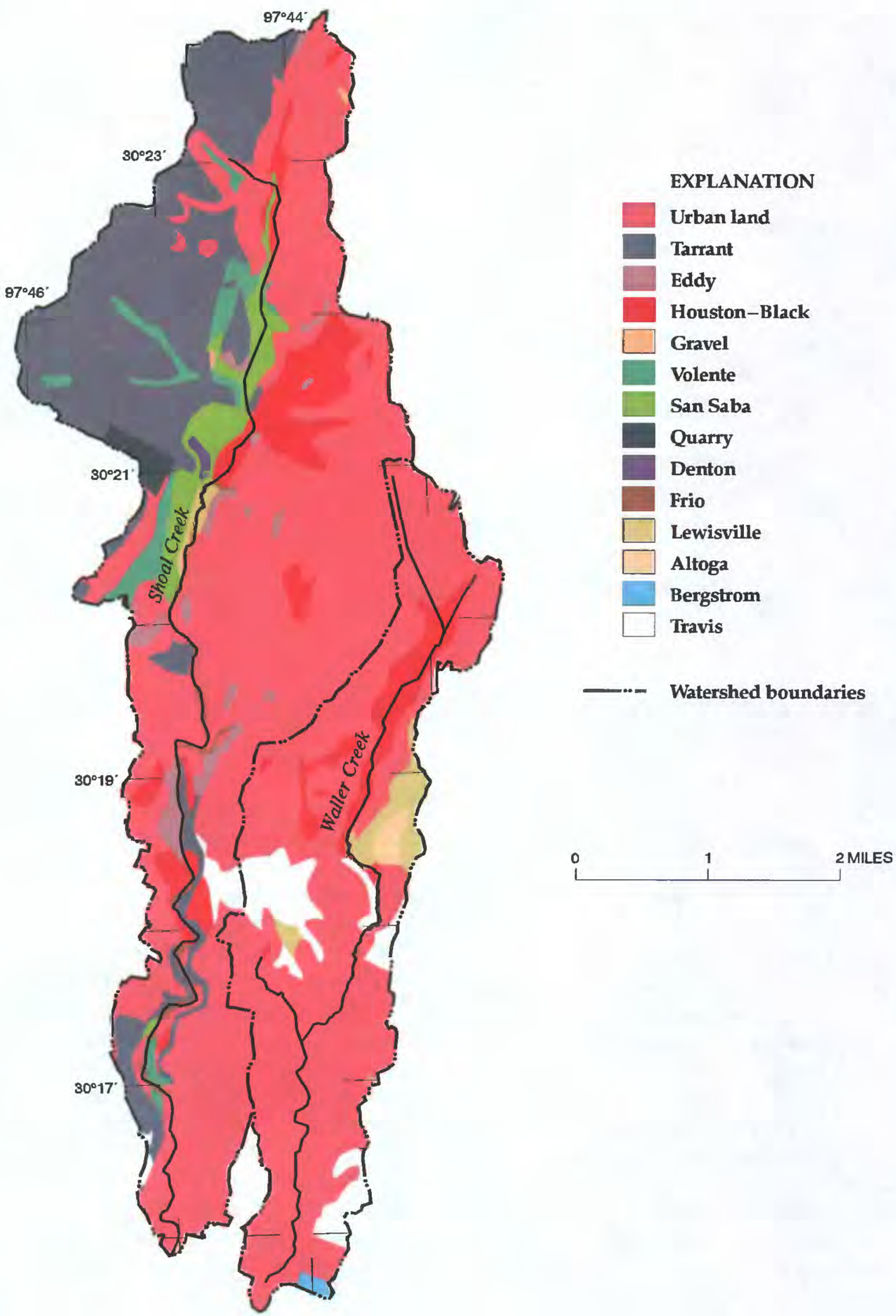

Figure 3. Soils for Shoal Creek and Waller Creek watersheds, Austin, Texas (Fatima Paiva, City of Austin, written commun., 1995). 


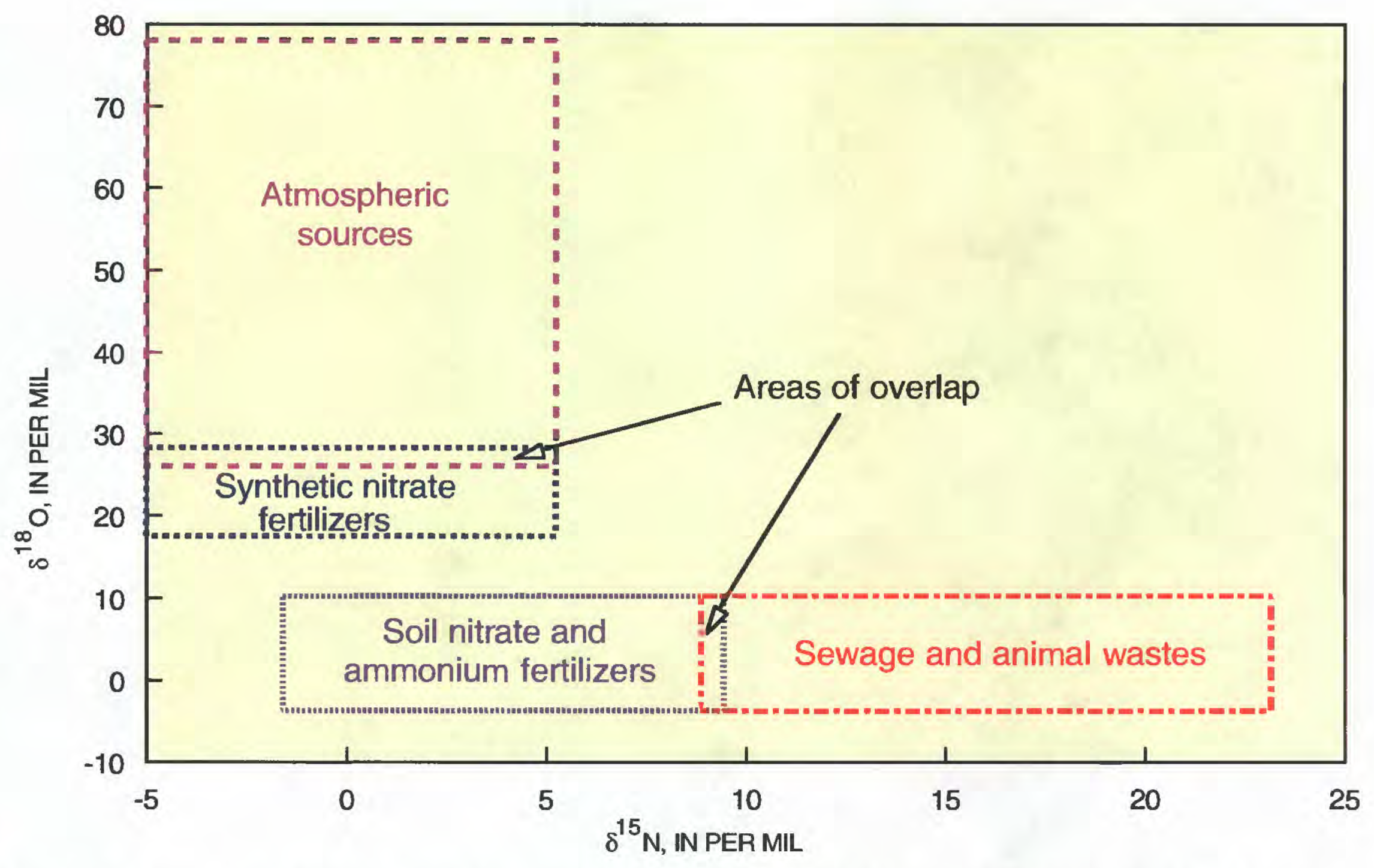

Figure 4. Approximate compositional ranges of $\delta^{15} \mathrm{~N}$ and $\delta^{18} \mathrm{O}$ data for sources of nitrate (Carol Kendall, U.S. Geological Survey, written commun., 1995).

U.S. Geological Survey, written commun., 1995). In addition, recent studies indicate that $\delta^{15} \mathrm{~N}$ and $\delta^{18} \mathrm{O}$ data in approximately a $2: 1$ ratio $\left(\delta^{15} \mathrm{~N}: \delta^{18} \mathrm{O}\right)$ could indicate denitrification (Amberger and Schmidt, 1987; Bottcher and others, 1990).

Nitrate formed from reduced nitrogen species obtains its oxygen in two parts from local water (atmospheric, surface, or ground water) and one part from dissolved oxygen ( $\delta^{18} \mathrm{O}$ cqual to about +23 per mil) (Amberger and Schmidt, 1987). Therefore, nitrate formed from decay products in the soil zone, from reduced nitrogen species in animal waste and sewage, and from synthetic ammonium fertilizers all tend to have similar $\delta^{18} \mathrm{O}$ values. Actual $\delta^{18} \mathrm{O}$ values of bacterially produced soil nitrate from recent studies averaged a few per mil heavier (ratios more positive) than predicted from two parts local ground water and one part dissolved oxygen because (1) local water in the soil zone underwent some evaporation and became isotopically heavier than predicted for the saturated zone, and (2) ground-water nitrate contains heavier $\delta^{18} \mathrm{O}$ values from nitrate fertilizers or atmospheric sources (Aravena and others, 1993; Wassenaar, 1995). The approximate compositional ranges depicted in figure 4 are drawn from these observations and from published and unpublished data (Heaton, 1986; Aravena and others, 1993; Durka and others, 1994; Wassenaar, 1995; Kendall and others, in press).

Conversion of nitrite to nitrogen (denitrification) can occur in slightly reducing geochemical environments where dissolved oxygen is low. Denitrification causes the remaining nitrate reservoir to become slightly heavier in the isotopic ratios of nitrogen and oxygen in the $\mathrm{NO}_{3}{ }^{-}$ion (Kendall and others, in press). Denitrification can occur in ground water, stagnant surface water, and some reducing soils, and could substantially alter nitrogen and oxygen isotopic ratios in these systems.

Solute and ion-pair ratio data can supplement nitrogen isotope data to identify sources of nitrate (Collins, 1975; Whittemore, 1988). Solutes that are conservative such as chloride, bromide, and iodide 
serve as tracers when transported with nitrate, resulting in ratios that might identify a nitrate source. Bromide and iodide tracers can identify components of fertilizer entering surface water. Dissolved chloride in conjunction with $\delta^{15} \mathrm{~N}$ data has been used to identify nitrate sources for municipal sewage (Avimelech and Raveh, 1976).

\section{Acknowledgments}

The project was done in cooperation with the City of Austin. Members of the Environmental and Conservation Services Department who participated in the project are George Chang, Project Manager; Jim Hubka and David Johns, scientific staff; Tom Brown, Steve Raymond, John Watkins, and Rene Avila, data collection. USGS staff who assisted with data collection are Mike Dorsey, Searcy Jacobs, Sonya Jones, and Joy Lizarraga.

\section{WATER CHEMISTRY OF SHOAL CREEK AND WALLER CREEK}

\section{Collection of Samples}

Samples were collected for chemical analysis at 7 sites in the 2 watersheds, 3 in the Shoal Creek watershed and 4 in the Waller Creek watershed, from September 1994 to April 1995 (fig. 1; tables 1, 2 at end of report). Samples were collected during 4 stormflow events and 3 base-flow periods for a total of 39 samples. Some sites did not sustain base flow and therefore baseflow samples were not collected at those sites. One sampling site, Shoal Crcek at MCC (site 1), was used as the best available background site. The other sampling sites were Shoal Creek at Woodhollow Drive (site 2), Shoal Creek at 12th Street (site 3), Waller Creek at 45th Street (site 4), Waller Creck at 38th Street (site 5), Waller Creek at Hancock golf course (site 6), and Waller Creek at 5th Street (site 7). Waller Creck at 45th Street and Waller Creek at 5th Street sampling sites are storm sewers draining into Waller Creck and are not on the main stem of the creek. Waller Creek at Hancock golf course sampling site is on a small tributary to Waller Creek. All other sampling sites are located on the main channels.

Sample collection was done primarily by the USGS. Staff of the City of Austin collected storm samples from sites 5, 6, and 7. For quality assurance, replicate samples and one equipment blank also were collected. An equipment blank is a sample of the deionized water used to decontaminate field equipment.
Three replicate samples from three locations at different times indicated that chemical constituent concentrations were within acceptable limits. The equipment blank showed no significant amounts of chemical constituents or fecal coliform. However, fecal streptococci measured 340 cols. $/ 100 \mathrm{~mL}$ in the equipment blank, indicating that some contamination of equipment was possible (table 2) and these data should be interpreted with caution.

Temperature, specific conductance, $\mathrm{pH}$, and alkalinity were measured in the field when possible. Water samples were analyzed at the USGS National Water Quality Laboratory in Denver, Colo., for major cations, major anions, and nutrients. The stable isotopes of nitrate, $\delta^{15} \mathrm{~N}$ and $\delta^{18} \mathrm{O}$, were analyzed by the USGS in Menlo Park, Calif. Fecal coliform and fecal streptococci bacteria were measured at the USGS laboratory in Austin, Tex.

\section{Chemical Characteristics}

Graphs of selected constituent concentrations grouped by sampling sites for Shoal Creek and Waller Creek watersheds illustrate variations of chemical concentrations for stormflow and base flow in the streams (figs. 5-7). With increased streamflow during storms, constituent concentrations, except for nitrate, phosphate, and bacteria, were consistently smaller in samples from both creeks. The smaller concentrations of most constituents in stormflow samples compared to base-flow samples probably were the result of dilution.

Solute concentrations were variable for both watersheds during stormflow and base flow. Magnesium concentrations are smaller toward watershed outlets during stormflow and during base flow on Shoal Creek (fig. 6). Sodium, chloride, and sulfate concentrations are larger toward watershed outlets during base flow (figs. 6, 7). These differences in concentrations toward the watershed outlets might not be typical. More sampling sites within each watershed are needed to define chemical changes toward the outlets. Solute concentrations of base flow at Shoal Creek at 12th Street probably were affected by wastewater discharge from local businesses rather than seepage from shallow ground water, based on field observation of discharge outfalls from nearby commercial areas. Solute concentrations during base-flow conditions from Waller Creek at 45 th Street might have been affected by leaks from a city water main. 

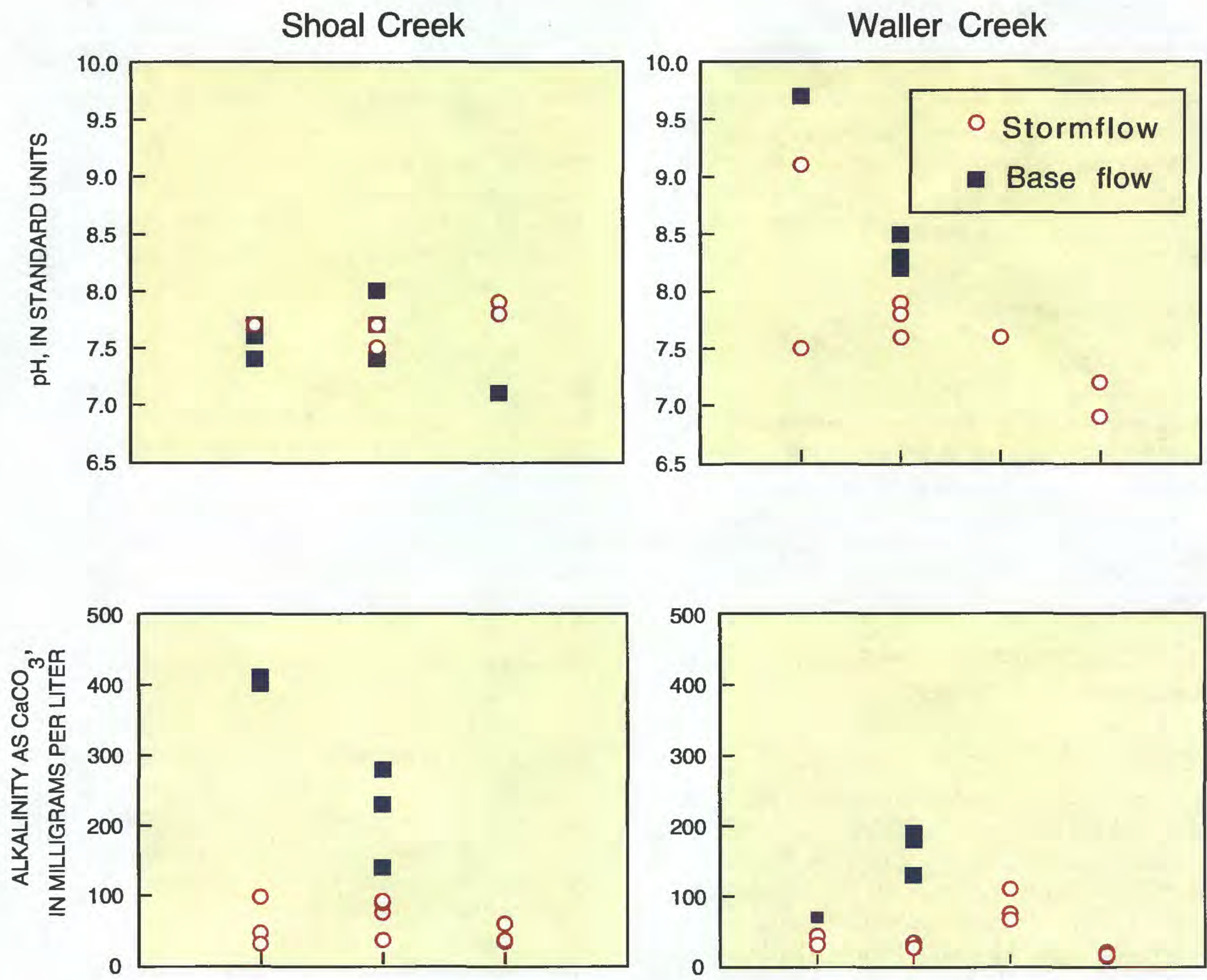

Shoal Creek Shoal Creek Shoal Creek
at MCC at Woodhollow at 12th Street

Waller Creek Waller Creek Waller Creek Waller Creek at 45th Street at 38th Street at Hancock at 5th Street
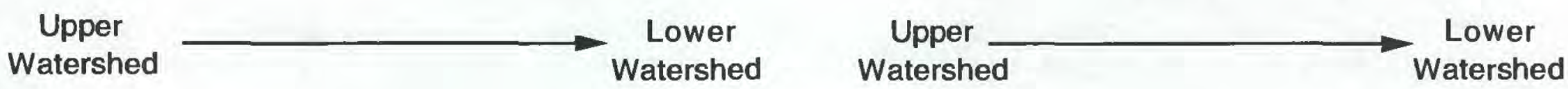

SAMPLING SITES

Figure 5. $\mathrm{pH}$ and alkalinity values grouped by sampling site for Shoal Creek and Waller Creek, Austin, Texas.

Bromide concentrations are near method detection limits for all samples taken in both watersheds (tables 1, 2); therefore any relation between bromide and nitrate sources could not be determined. Some sites indicate excess chloride concentrations with respect to sodium concentrations (greater than $1: 1$ mole ratio of chloride to sodium) (fig. 8), but no correlation between nitrate and chloride concentrations could be determined. Samples with excess chloride with respect to sodium could indicate sewage contamination (Avimelech and Raveh, 1976).

Nitrate (as N) concentrations in samples collected from the Shoal Creek watershed range from 0.19 to $0.75 \mathrm{mg} / \mathrm{L}$ in stormflow and from 0.02 to $1.9 \mathrm{mg} / \mathrm{L}$ 

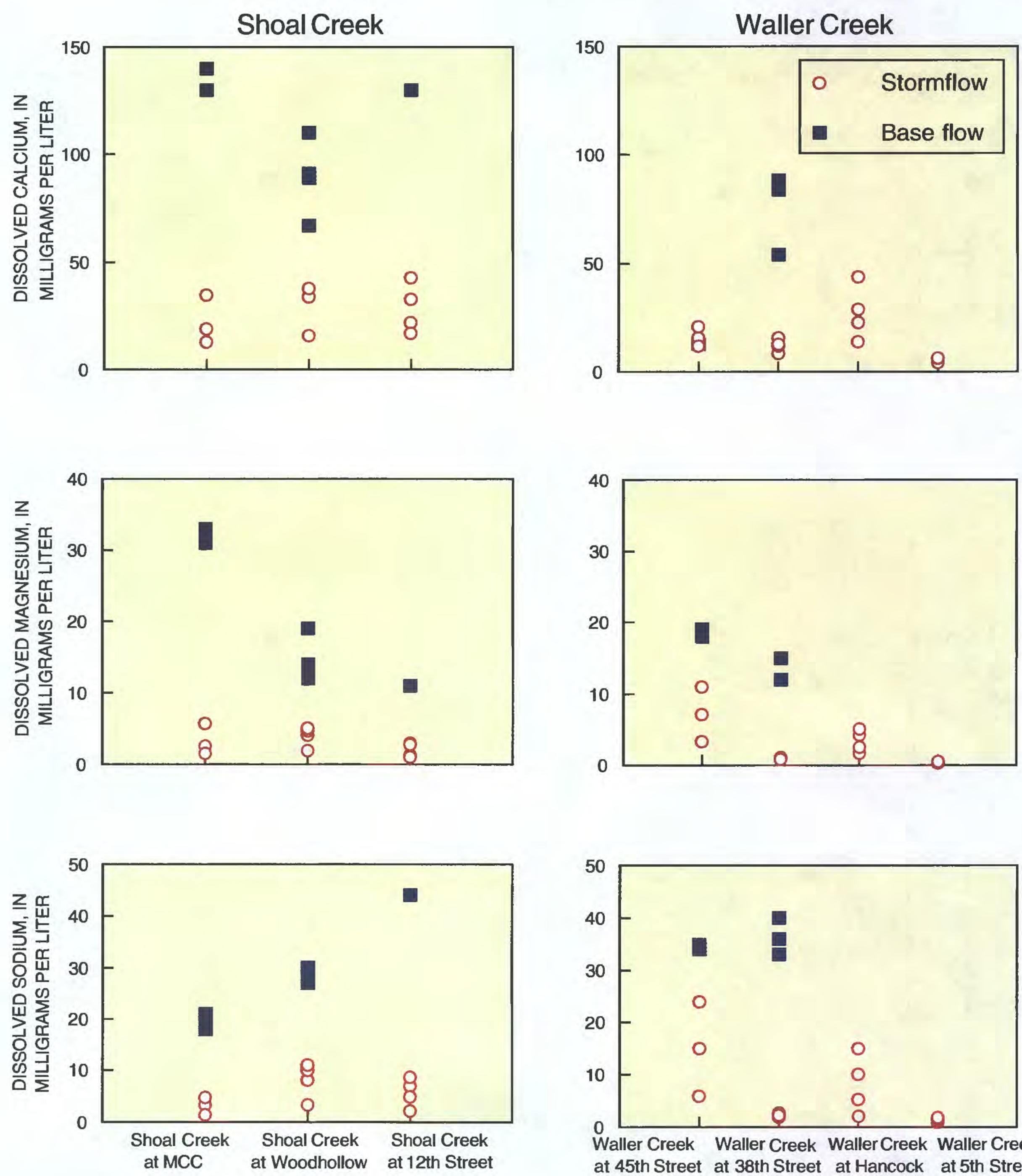

Waller Creek Waller Creek Waller Creek Waller Creek at 45th Street at 38th Street at Hancock at 5th Street
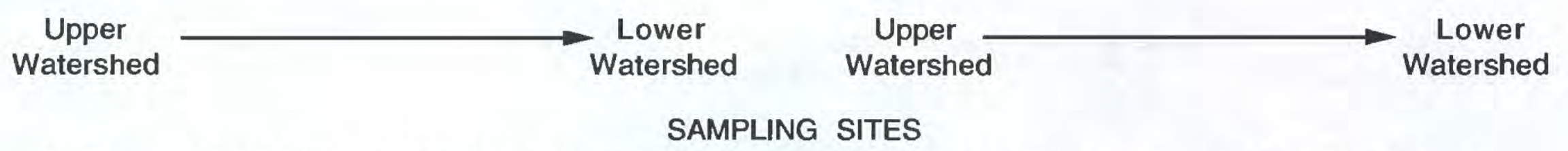

Figure 6. Dissolved calcium, magnesium, and sodium concentrations grouped by sampling site for Shoal Creek and Waller Creek, Austin, Texas. 
Shoal Creek
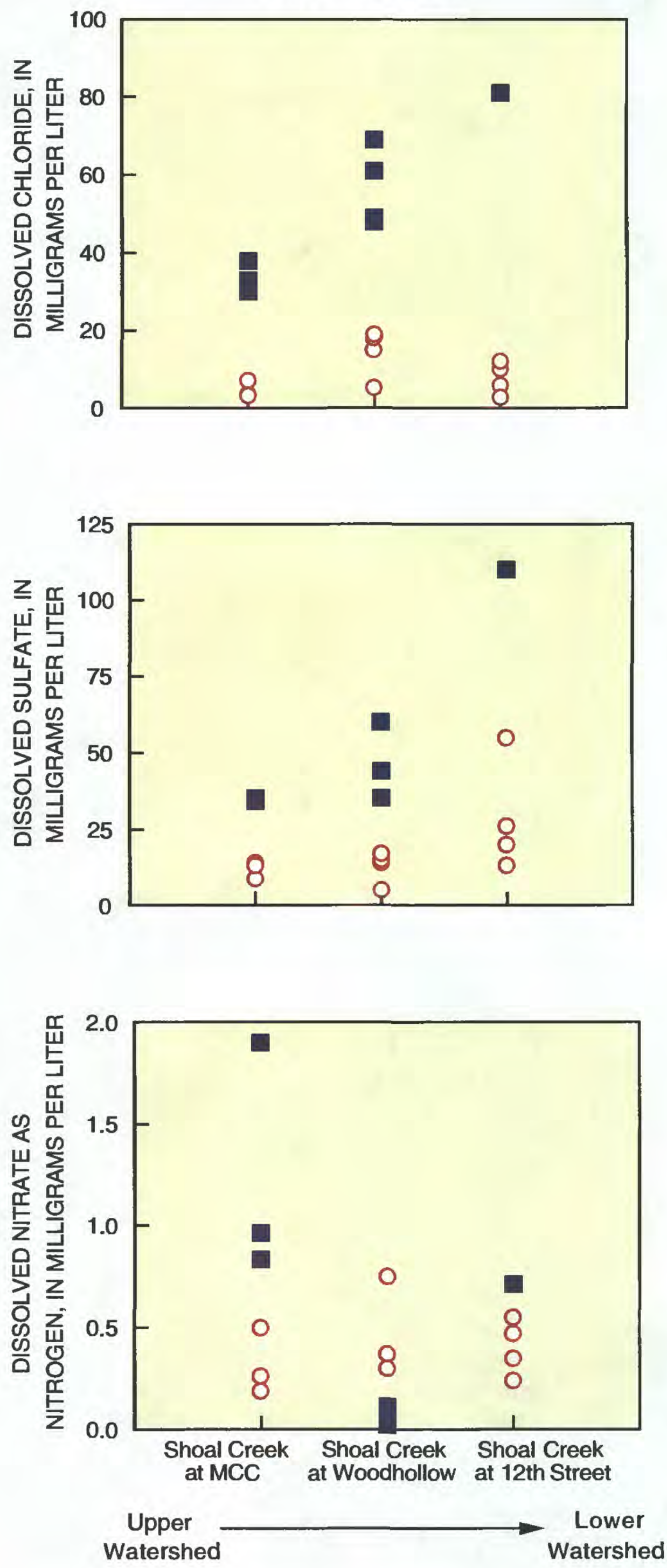

Waller Creek
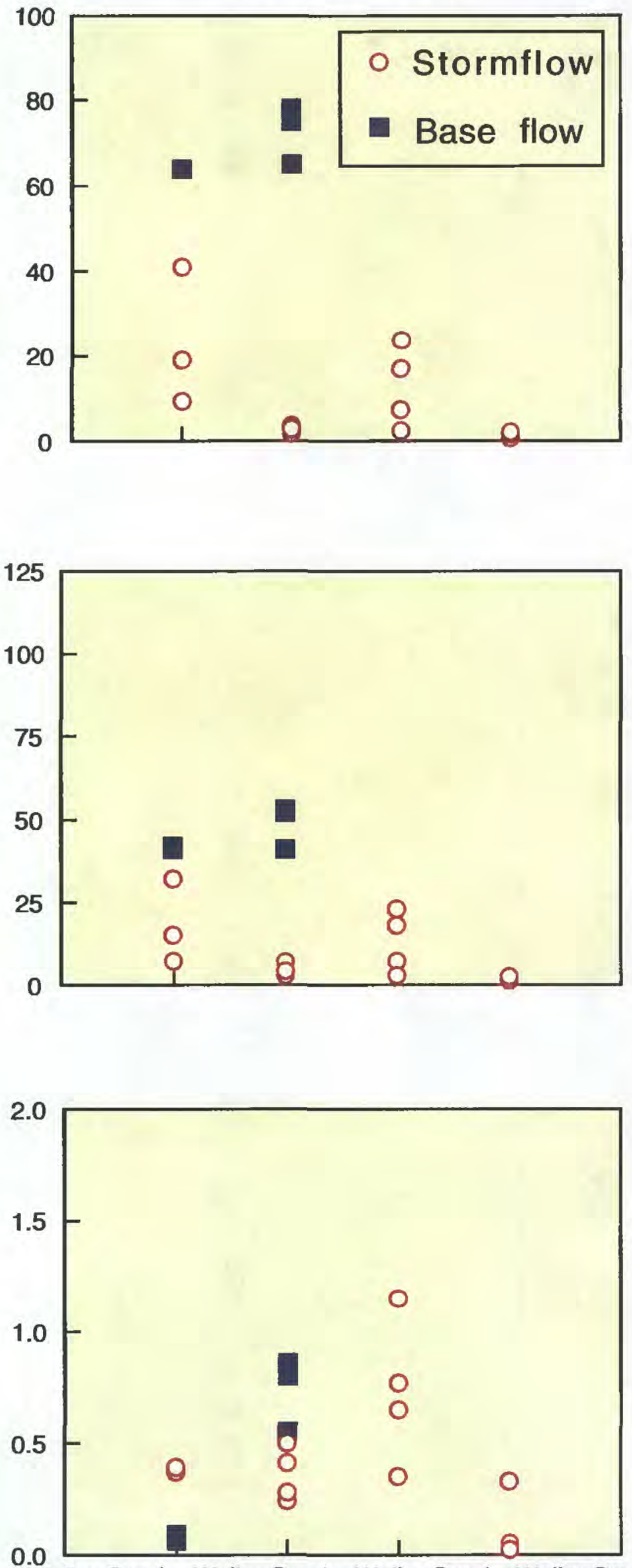

Waller Creek Waller Creek Waller Creek Waller Creek at 45th Street at 38th Street at Hancock at 5th Street

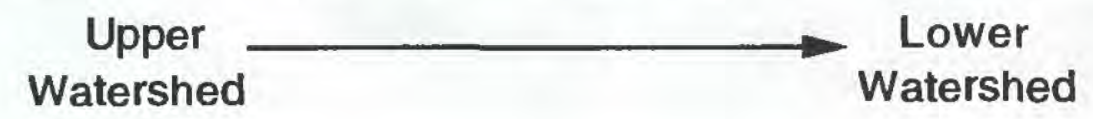

\section{SAMPLING SITES}

Figure 7. Dissolved chloride, sulfate, and nitrogen concentrations grouped by sampling site for Shoal Creek and Waller Creek, Austin, Texas. 


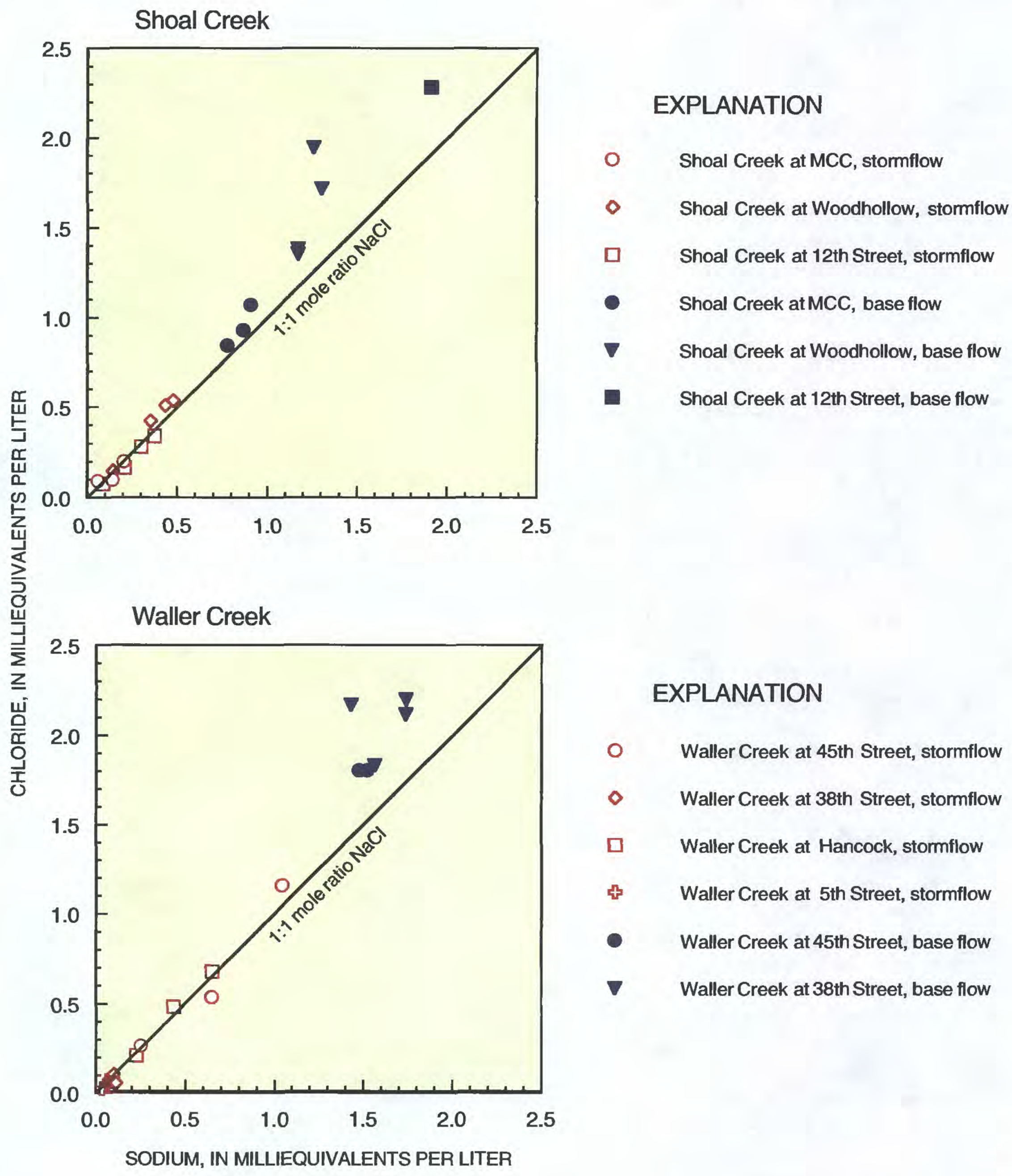

Figure 8. Relations between sodium and chloride concentrations in stormflow and base flow for Shoal Creek and Waller Creek, Austin, Texas. 
in base flow (below the MCL of $10 \mathrm{mg} / \mathrm{L}$ ) (tables 1,2 ). In samples collected from the Waller Creek watershed, nitrate (as $\mathrm{N}$ ) concentrations range from 0.02 to 1.2 $\mathrm{mg} / \mathrm{L}$ in stormflow and from 0.06 to $0.86 \mathrm{mg} / \mathrm{L}$ in base flow. Nitrate concentrations are larger in stormflow samples in Waller Creek at Hancock golf course (where no base flow occurred) than in stormflow at the other sites.

In the combined Shoal Creek and Waller Creek watersheds, fecal coliform counts range from less than 1 to 84,000 cols. $/ 100 \mathrm{~mL}$, and fecal streptococci counts range from less than 1 to 310,000 cols. $/ 100 \mathrm{~mL}$ in stormflow, indicating relatively high levels of fecal bacteria in runoff (table 1). Ratios of fecal coliform to fecal streptococci below 0.7 indicate animal sources of fecal bacteria (American Public Health Association, 1981). Ratios above 4.1 indicate human sources. Ratios in the range of 0.7 to 4.1 indicate mixes from both sources. Most ratios of fecal coliform to fecal streptococci are less than 0.7 in stormflow samples, indicating that the source of bacteria is predominantly from animal wastes. In base flow, fecal coliform counts range from less than 1 to 1,600 cols. $/ 100 \mathrm{~mL}$, and fecal streptococci counts range from less than 1 to 960 cols./100 $\mathrm{mL}$ for both watersheds, indicating much lower levels of fecal bacteria in base flow than stormflow in the watersheds (table 2). Less than $1 \mathrm{col} . / 100 \mathrm{~mL}$ recorded for bacteria at various times at the Waller Creek at 45 th Street site might be a result of chlorinated water leaking from a water line into the creek, killing most or all fecal bacteria. $\mathrm{pH}$ values exceeding 9.0 with low alkalinity at this site, similar to values for city of Austin tap water (P.C. Bennett, University of Texas at Austin, oral commun., 1995), also indicate a leaking water line.

Trilinear diagrams indicate general water type using the major cation and major anion data from the water samples (figs. 9, 10). The water type in both Shoal Creek and Waller Creek is calcium bicarbonate, which is expected in a limestone terrane. Calculated dissolved solids in water samples collected from the Shoal Creek and Waller Creek watersheds range from 16 to $187 \mathrm{mg} / \mathrm{L}$ for stormflow samples and from 213 to $499 \mathrm{mg} / \mathrm{L}$ for base-flow samples. Dissolved solids concentrations generally are 2 to 4 times greater during base flow than during stormflow (tables 1,2 ). Constituent concentrations in the samples collected for this project are typical for water from urbanized areas; and they are within ranges of recommended drinking-water standards (U.S. Environmental Protection Agency, 1996).

\section{POTENTIAL SOURCES OF NITRATE}

The potential sources of nitrate in the Shoal Creek and Waller Creek watersheds include fertilizers, sewage, animal wastes, atmospheric, and soil sources. Each source contributes a distinct nitrogen and oxygen isotopic signature in the nitrate ion (fig. 4).

Graphs of $\delta^{15} \mathrm{~N}$ and $\delta^{18} \mathrm{O}$ data relative to compositional ranges for sources of nitrate for the most part show distinct separation between stormflow and baseflow samples for the Shoal Creek and Waller Creek watersheds (fig. 11). Isotopic data for stormflow samples $\left(\delta^{15} \mathrm{~N}\right.$ from +1.7 to $+10.6 \mathrm{per}$ mil and $\delta^{18} \mathrm{O}$ from +8.9 to +39.5 per mil) are in or near the isotopic composition range of synthetic nitrate fertilizer. However, synthetic nitrate fertilizer is an unlikely source of nitrate because most fertilizers applied to land surface in the watersheds are ammonium fertilizers (George Chang, City of Austin, oral commun., 1996). Because synthetic nitrate fertilizer is not a likely source of nitrate, the isotopic data for stormflow probably represents combinations of atmospheric nitrate, and soil nitrate and ammonium fertilizer sources. Although concentrations of nitrate in rainfall generally are small (table 3), atmospheric nitrate could contribute to the total nitrate load and affect the range of isotopic data. Isotopic data for base-flow samples $\left(\delta^{15} \mathrm{~N}\right.$ from +8.4 to +13.1 per mil and $\delta^{18} \mathrm{O}$ from -0.08 to +19.0 per mil) are in or near the isotopic composition ranges for soil nitrate and ammonium fertilizer, and sewage and animal waste sources of nitrate.

Livestock or animals other than domestic pets and urban/suburban-dwelling mammals and birds are not known to be in the watersheds. However, sewage contamination of ground water from sewer lines and (or) septic tanks could be substantial in older residential areas (more than 20 years old). In time, sewer lines and (or) septic tanks degrade, possibly leaking sewage containing nitrate into the ground water. In addition. the sewer lines commonly are in or near the creek beds; therefore, leakage from these lines can discharge directly into the stream. Shoal Creek and Waller Creek pass through older parts of Austin, about one-half of which are residential areas older than 20 years (George Chang, City of Austin, oral commun., 1995).

Geographic information system (GIS) coverage of land use was available for the Waller Creek watershed to allow some interpretation of the isotopic data with respect to land use represented by the sample sites. Mean concentrations of dissolved nitrate increase 


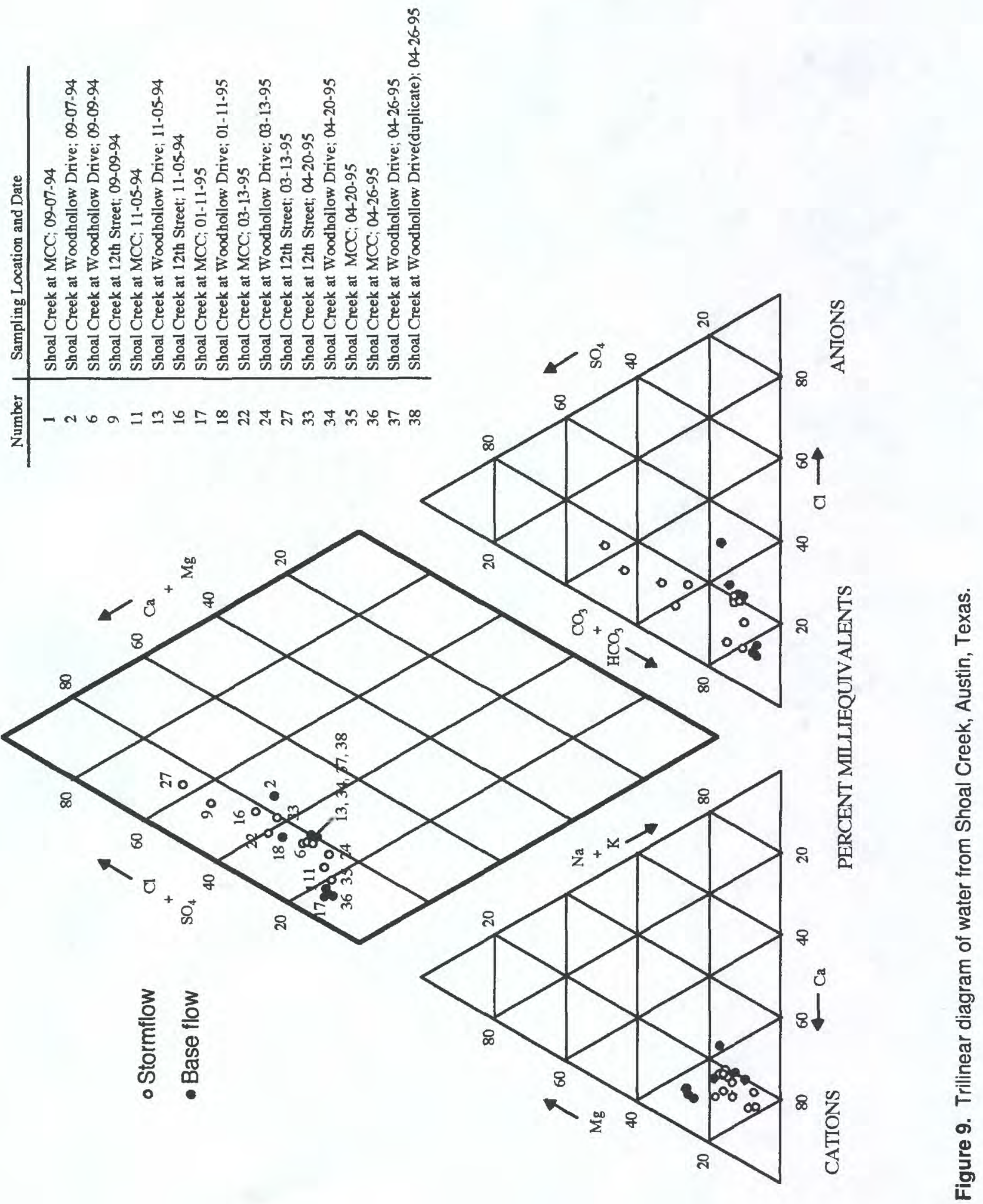



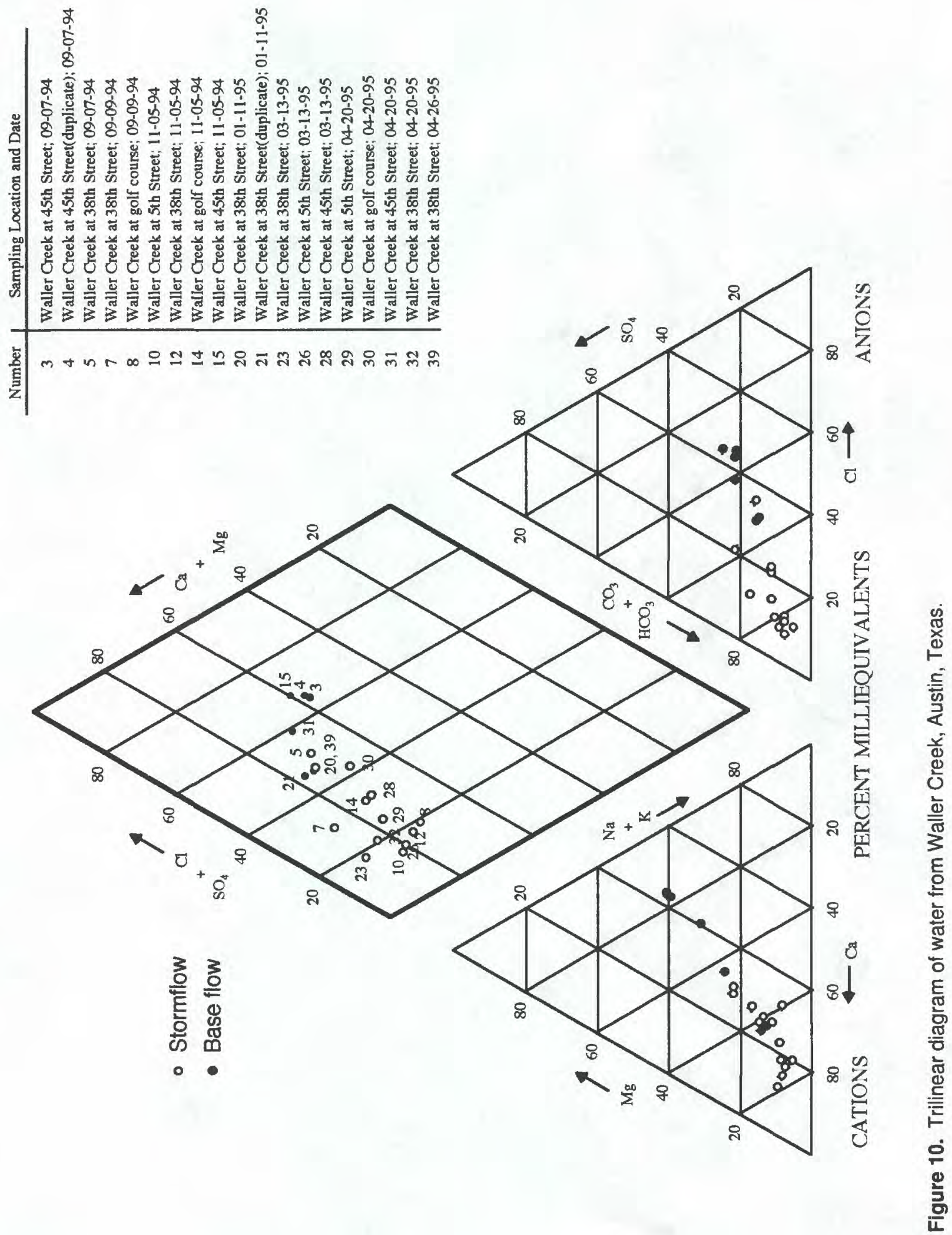


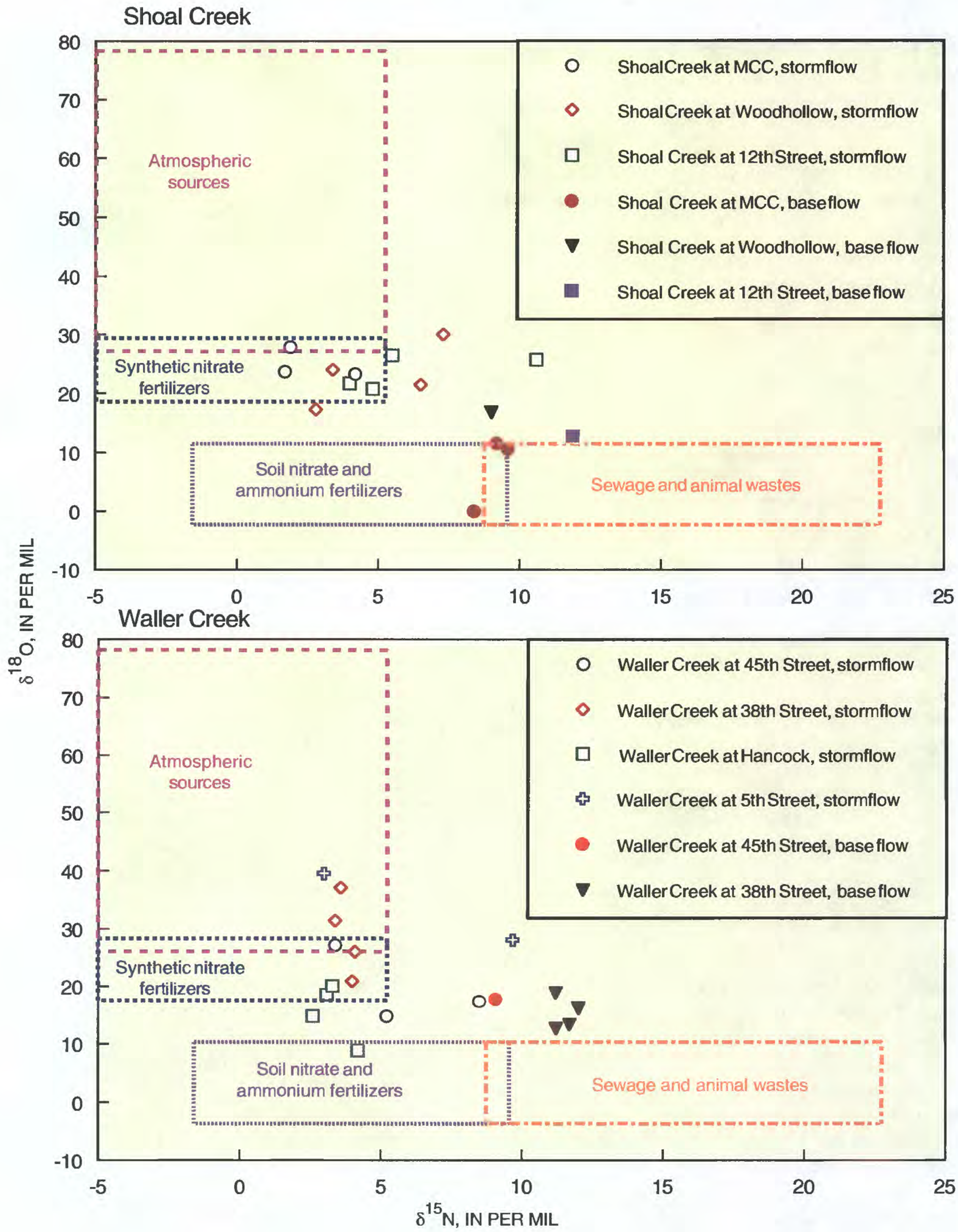

Figure 11. $\delta^{15} \mathrm{~N}$ and $\delta^{18} \mathrm{O}$ data for stormflow and base-flow samples from Shoal Creek and Waller Creek, Austin, Texas, relative to compositional ranges for sources of nitrate. 
Table 3. Selected chemical data for rainfall samples taken near Shoal Creek and Waller Creek watersheds, Austin, Texas

[mg/L, milligrams per liter; cols./100 mL, colonies per 100 milliliters; --, no data; <, less than]

\begin{tabular}{ccccr}
\hline $\begin{array}{c}\text { Sample } \\
\text { date }\end{array}$ & $\begin{array}{c}\text { Dissolved } \\
\text { nitrate, } \\
\text { as } \mathrm{N} \\
(\mathrm{mg} / \mathrm{L})\end{array}$ & $\begin{array}{c}\text { Phosphate, } \\
\text { (as } \mathrm{PO}_{4}^{-3} \text { ) } \\
\text { dissolved } \\
(\mathbf{m g} / \mathrm{L})\end{array}$ & $\begin{array}{c}\text { Fecal } \\
\text { coliform } \\
\text { (cols./100 mL) }\end{array}$ & $\begin{array}{c}\text { Fecal } \\
\text { streptococci } \\
\text { (cols./100 mL) }\end{array}$ \\
\hline $10-20-93$ & 3.8 & 0.08 & 0 & 0 \\
$02-28-94$ & .11 & .10 & 0 & 50 \\
$03-10-94$ & .05 & .05 & -- & $-2,000$ \\
$03-13-94$ & .24 & $<.05$ & -- & - \\
$04-05-94$ & .11 & .18 & 0 & 5,300 \\
$04-11-94$ & -- & $<.05$ & -- & - \\
$05-03-94$ & .12 & $<.005$ & -- & - \\
\hline
\end{tabular}

Joseph Malina, University of Texas at Austin, written commun., 1995.

Table 4. Average nitrate concentrations, oxygen-18 values, and land-use information for stormflow and baseflow samples from Waller Creek, Austin, Texas

[mg/L, milligrams per liter; per mil, parts per thousand]

\begin{tabular}{clcccl}
\hline $\begin{array}{c}\text { Sample } \\
\text { site no. } \\
\text { (fig. 1) }\end{array}$ & Station name & $\begin{array}{c}\text { Average } \\
\text { dissolved } \\
\text { nitrate as } \mathbf{N} \\
(\mathbf{m g} / \mathbf{L})\end{array}$ & $\begin{array}{c}\text { Average } \\
\delta^{18} \mathbf{O} \\
\text { (per } \mathbf{~ m I )}\end{array}$ & $\begin{array}{c}\text { Impervious } \\
\text { cover } \\
\text { (percent) }\end{array}$ & Land use \\
\hline 6 & Waller Creek at Hancock golf course & 0.76 & 15.6 & 10.0 & Golf course \\
4 & Waller Creek at 45th Street & .39 & 19.8 & 43.2 & Suburban \\
5 & Waller Creek at 38th Street & .37 & 28.9 & 46.8 & Urban/suburban \\
7 & Waller Creek at 5th Street & .14 & 31.7 & 93.0 & Urban \\
\hline
\end{tabular}

and isotopes of oxygen become lighter (ratios more negative) with decreasing impervious cover for the land uses represented by the samples (table 4) (Jim Hubka, City of Austin, written commun., 1996).

Concentrations of nitrate from Waller Creek at 5th Street were lowest and the $\delta^{18} \mathrm{O}$ values heaviest among all samples for the watershed. Low concentrations of nitrate and heavy $\delta^{18} \mathrm{O}$ values are consistent with a predominantly atmospheric source of nitrate (fig. II, table 3). The stormflow samples from Waller Creek at 5th Street represent drainage from a subwatershed with more than 90 percent impervious cover (table 4), which would tend to minimize nitrate from fertilizer sources, soil sources, and sewage and animal wastes; thus nitrate concentrations and $\delta^{18} \mathrm{O}$ data from a site associated with an essentially impervious drainage area are consistent with a predominantly atmospheric source of nitrate.

Greater mean nitrate concentrations and lighter $\delta^{18} \mathrm{O}$ values in samples from the three sites in the Waller Creek watershed associated with less impervious cover (table 4) indicate sources of nitrate in addition to atmospheric nitrate (fig. 11). Specifically, the nitrate and isotopic data from stormflow samples at 45th Street, 38th Street, and Hancock golf course reflect combinations of atmospheric nitrate, and soil nitrate and ammonium fertilizer sources (assuming, as previously stated, that there is little or no use of 
synthetic nitrate fertilizers in the watershed); whereas the nitrate and isotopic data from base-flow samples from Waller Creek at 45 th and 38 th Streets are most consistent with a sewage and animal waste source of nitrate.

Excess chloride concentrations relative to sodium have been used in previous investigations at other locations as tracers of sewage contamination (Avimelech and Raveh, 1976). Graphs of relations between sodium and chloride concentrations in stormflow and base flow indicate a source of excess chloride relative to sodium at some sampling sites, particularly under base-flow conditions (fig. 8). These sites are Shoal Creek at Woodhollow, Shoal Creek at 12th Street, Waller Creek at 45th Street, and Waller Creck at 38th Street. Excess chloride concentrations relative to sodium at Waller Creek at 45 th Strect could be the result of chlorinated drinking water leaking into the creek. Chloride-to-sodium molar ratios greater than I at the other sites indicate that base flows in Shoal Creck and Waller Creek could have contained sewage effluent, which would be consistent with the $\delta^{15} \mathrm{~N}$ and $\delta^{18} \mathrm{O}$ data.

Figure 12 shows $\delta^{15} \mathrm{~N}$ and $\delta^{18} \mathrm{O}$ averages by sampling datc. The correspondence in trends between $\delta^{15} \mathrm{~N}$ and $\delta^{18} \mathrm{O}$ from one sampling date to the next indicates that the measured values are responding to varying proportions of two general endmember compositions: one of relatively low $\delta^{15} \mathrm{~N}$ and high $\delta^{18} \mathrm{O}$ and the other of relatively high $\delta^{15} \mathrm{~N}$ and low $\delta^{18} \mathrm{O}$. Figure 13 shows all of the isotopic data for the stormflow and base-flow samples and ellipses having radii of 2 standard deviations from average superimposed to highlight the distinction between sources of nitrate in stormflow and base-flow samples. The data of figures 12 and 13 are consistent with the conclusion that nitrate concentrations in the creeks at any given time are mixtures resulting from surface sources (atmospheric nitrate, and soil nitrate and ammonium fertilizer) during stormflow and predominantly from subsurface sources (sewage and soil nitrate and ammonium fertilizer) during base flow.

Denitrification is not a likely cause of the heavy $\delta^{15} \mathrm{~N}$ values because the samples were collected from oxygenated surface waters. Furthermore, there is no apparent tendency among the base-flow samples toward heavier isotopic ratios of $\delta^{18} \mathrm{O}$ in the nitrate ion (fig. I1), a likely characteristic if denitrification were occurring (Kendall and others, in press).

\section{CONCLUSIONS}

In general, stormflow in the Shoal Creek and Waller Creek watersheds contains smaller amounts of dissolved constituents than base flow. Magnesium concentrations decrease toward basin outlets during baseflow conditions; whereas, other constituent concentrations (sodium, chloride, and sulfate) increase toward basin outlets during base-flow conditions. Nitrate (as N) concentrations are below the MCL of $10 \mathrm{mg} / \mathrm{L}$. Fecal bacteria counts are greater in stormflow samples than in base-flow samples.

The general water type in the Shoal Creek and Waller Creek watersheds is calcium bicarbonate, which is common in limestone terranes.

$\delta^{15} \mathrm{~N}$ and $\delta^{18} \mathrm{O}$ isotopic data from dissolved nitrate indicate that the sources of nitrate in stormflow of both watersheds probably are not the same as the sources of nitrate in base flow.

$\delta^{15} \mathrm{~N}$ and $\delta^{18} \mathrm{O}$ isotopic data in nitrate for stormflow samples are in or near the isotopic composition ranges for atmospheric nitrate, and soil nitrate and ammonium fertilizer sources. A combination of atmospheric nitrate, and soil nitrate and ammonium fertilizer sources is the most likely cause of nitrate in stormflow samples (assuming that there is little or no use of synthetic nitrate fertilizers in the watersheds).

$\delta^{15} \mathrm{~N}$ and $\delta^{18} \mathrm{O}$ isotopic data in nitrate for baseflow samples are in or near the isotopic composition ranges for soil nitrate and ammonium fertilizer, and sewage and animal waste sources of nitrate. A combination of sewage nitrate and soil nitrate and ammonium fertilizer sources is the most likely source of nitrate in base-flow samples. Sewage is considered the predominant source because of the potential for older sewer lines to degrade, the proximity of sewer lines to creek beds, and an excess of chloride relative to sodium at some sampling sites (an indicator of the presence of sewage) under base-flow conditions.

Impervious cover could restrict the primary nitrate source to atmospheric. In the Waller Creek watershed, nitrate concentrations, and $\delta^{15} \mathrm{~N}$ and $\delta^{18} \mathrm{O}$ isotopic data in nitrate for stormflow samples from one site that represents drainage from an essentially impervious subwatershed indicate an atmospheric source is most likely; whereas nitrate and isotopic data from stormflow samples representing three subwatersheds with less than 50-percent impervious cover indicate possible soil nitrate and ammonium fertilizer sources in addition to atmospheric sources. 

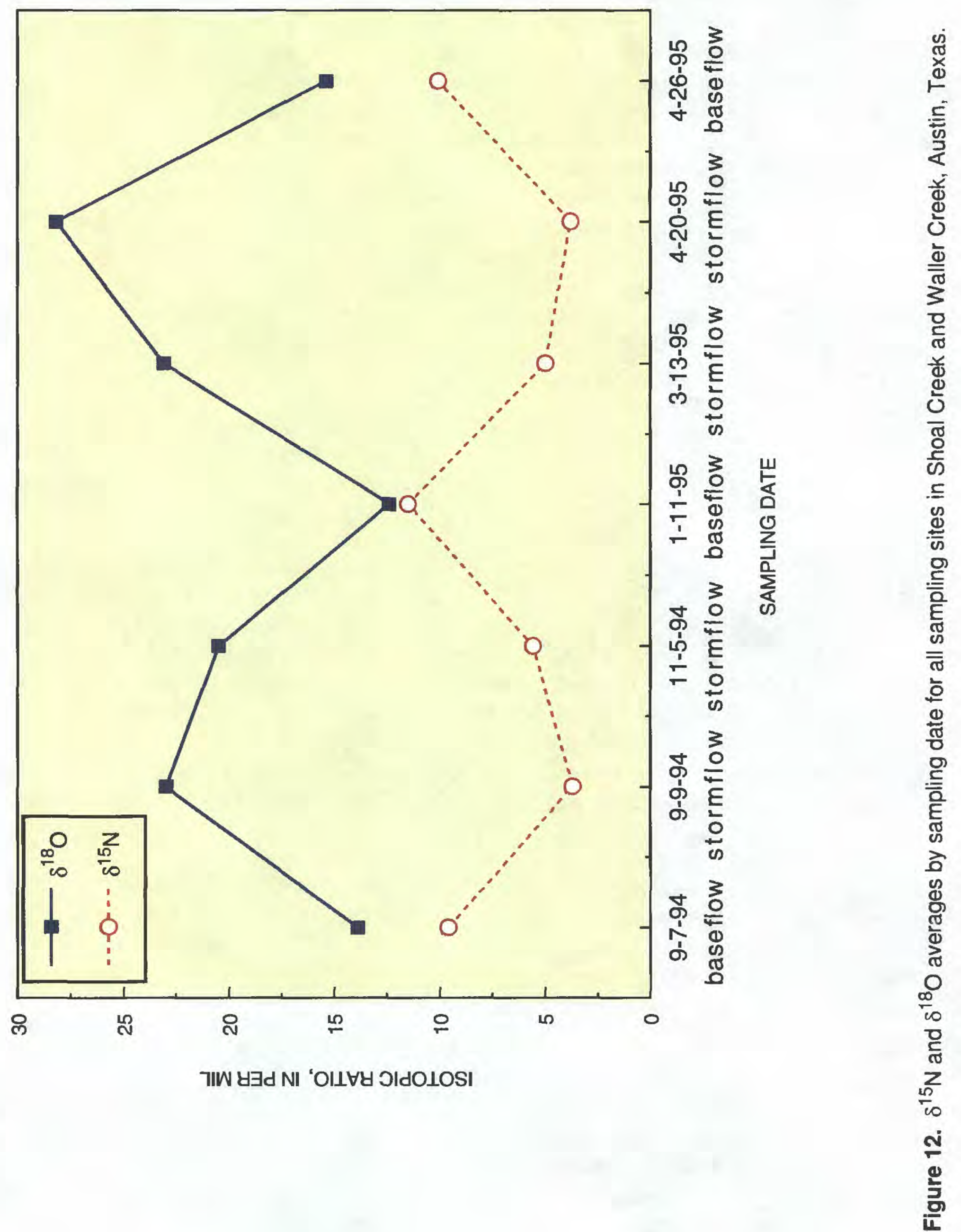


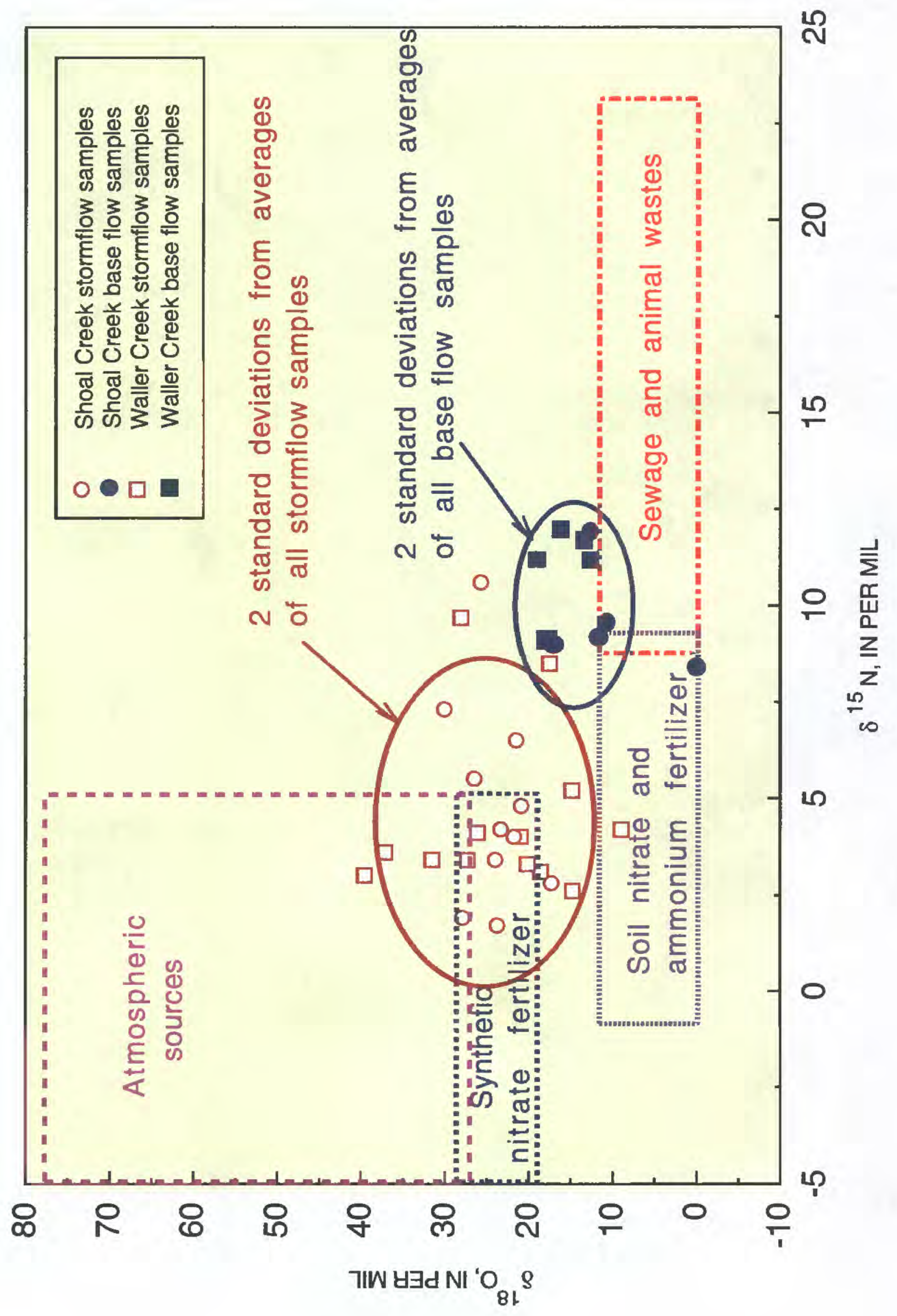

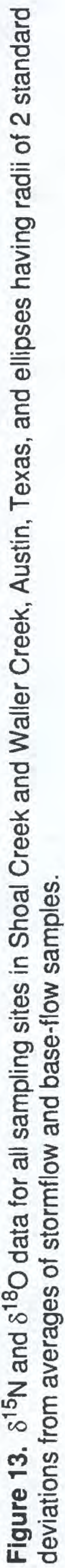




\section{REFERENCES}

Amberger, A., and Schmidt, H., 1987, Naturliche isotopengehalte von nitrat als indikatoren fur dessen herkunft: Geochimica et Cosmochimica Acta, v. 51, p. 2,699-2.705.

American Public Health Association, 1981, Standard methods for the examination of water and wastewater: 15 th ed.

Aravena, R., Evans, M., and Cherry, J., 1993, Stable isotopes of oxygen and nitrogen in source identification of nitrate from septic systems: Groundwater, v. 31, p. $180-186$.

Avimelech, Y., and Raveh, J., 1976, Nitrate leakage from soils differing in texture and nitrogen load: Journal of Environmental Quality, v. 5, p. 79-81.

Bottcher, J., Strebel, O., Voerkelius, S., and Schmidt, H., 1990, Using isotope fractionation of nitrate-nitrogen and nitrate-oxygen for evaluation of microbial denitrification in a sandy aquifer: Journal of Hydrology, v. 114. p. 413- 424 .

City of Austin, Environmental and Conservation Services Department, 1990a, Removal efficiencies of stormwater control structures: $42 \mathrm{p}$.

$1990 \mathrm{~b}$, Stormwater pollutant loading characteristics for various land uses in the Austin area: $77 \mathrm{p}$.

Collins, A., 1975, Geochemistry of oilfield waters, in Developments in petroleum science: New York, Elsevier Publishing Co., p. 496.

Durka, W., Schulze, E., Gebauer, G., and Voerkelius, S., 1994, Effects of forest decline on uptake and leaching of deposited nitrate determined from ${ }^{15} \mathrm{~N}$ and ${ }^{18} \mathrm{O}$ measurements: Nature, v. 372, p. 765-769.
Fritz, Peter, and Fontes, J.C., 1980, Introduction, in Fritz, Peter, and Fontes, J.C., eds., Handbook of environmental isotope geochemistry, v. 1, The terrestrial environment, A: Amsterdam, The Netherlands, Elsevier Publishing Co., p. 1-19.

Heaton, T., 1986, Isotopic studies of nitrogen pollution in the hydrosphere and atmosphere $-A$ review: Chemical Geology, v. 59, p. 87-102.

Kendall, C., Silva, S., Chang, C., Burns, D., Campbell, D., and Shanley, J., in press, Use of the $\delta^{15} \mathrm{~N}$ and $\delta^{18} \mathrm{O}$ of nitrate to determine sources of nitrate in early spring runoff in forested catchments, in Conference and International Symposium on Isotopes in Water Resources Management, Vienna, Austria, March 20-14, 1995, Proceedings: International Atomic Energy Agency.

U.S. Department of Agriculture, Soil Conservation Service, 1974, Soil survey of Travis County, Texas: Washington, D.C., 123 p.

U.S. Environmental Protection Agency, 1996, Drinking water regulations and health advisories: Washington, D.C., Office of Water, 16 p.

Wassenaar, L., 1995, Evaluation of the origin and fate of nitrate in the Abbotsford aquifer using the isotopes of ${ }^{15} \mathrm{~N}$ and ${ }^{18} \mathrm{O}$ in $\mathrm{NO}_{3}{ }^{-}$: Applied Geochemistry, v. 10 . p. $391-405$.

Welborn, C.T., and Veenhuis, J.E., 1987, Effects of runoff controls on the quantity and quality of urban runoff at two locations in Austin, Texas: U.S. Geological Survey Water-Resources Investigations Report 87-4004, $101 \mathrm{p}$.

Whittemore, D., 1988, Bromide as a tracer in ground-water studies - Geochemistry and analytical determination, in Conference on Ground Water Geochemistry, Denver, Colo., February 16-18, 1988, Proceedings: p. 339-354. 


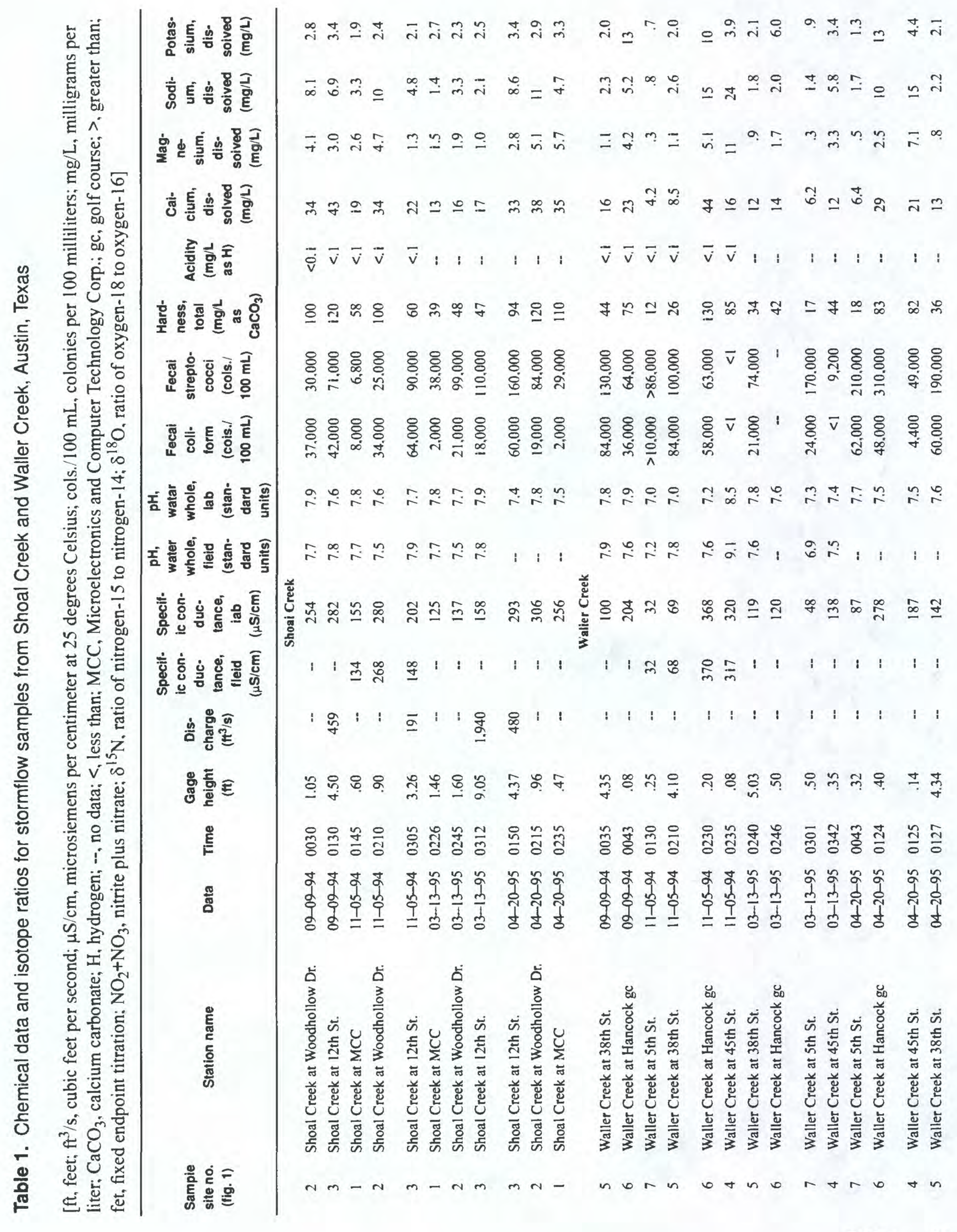




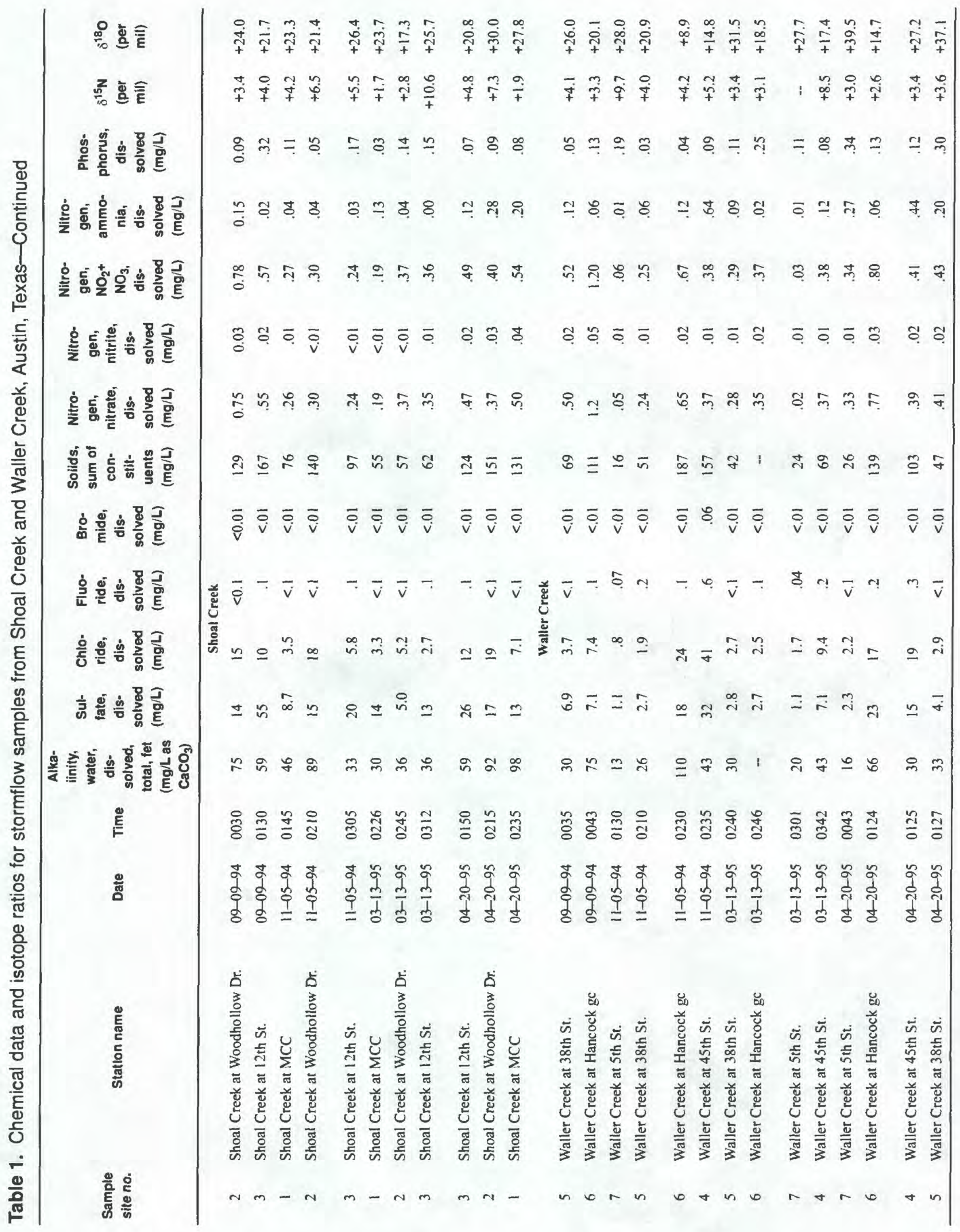




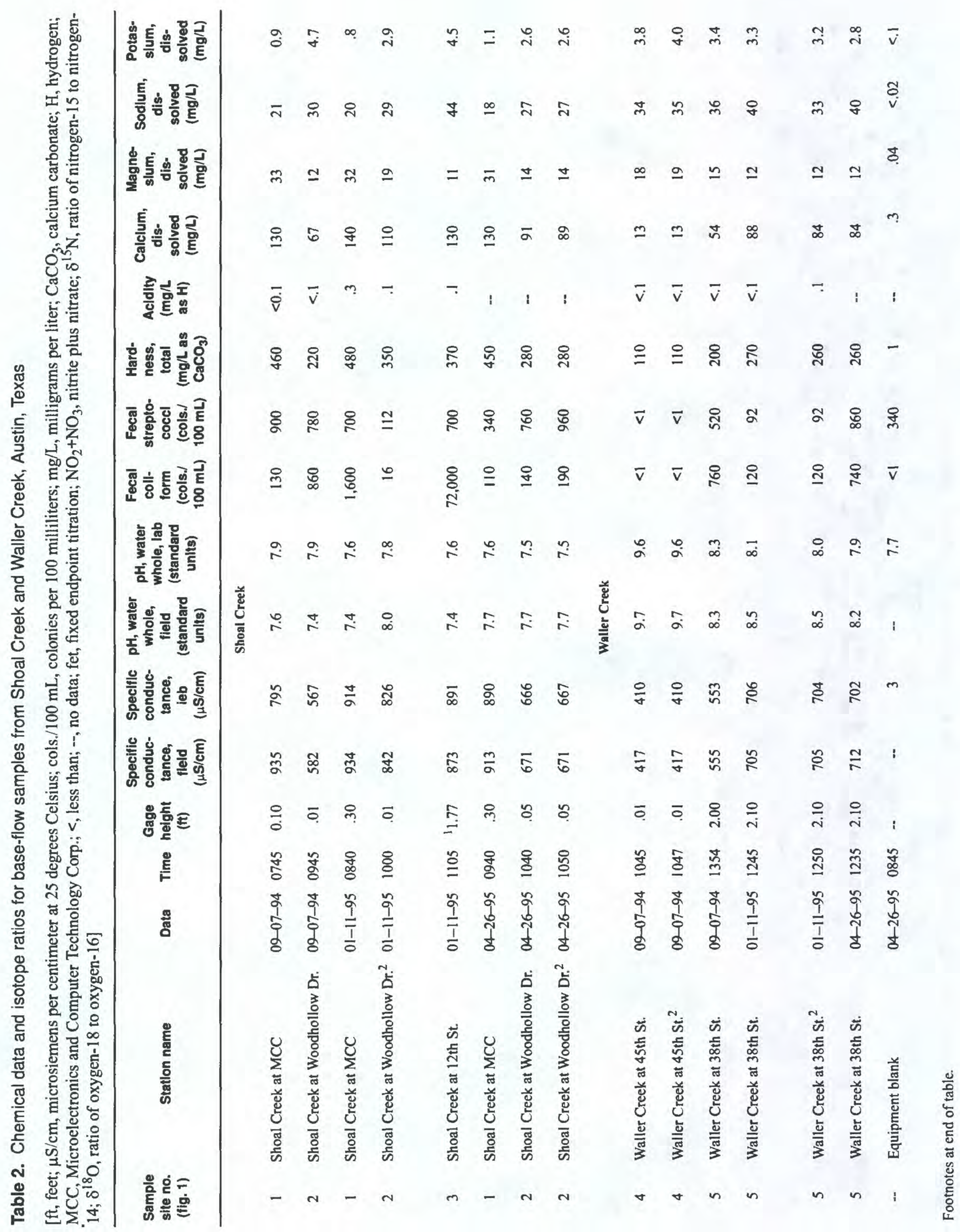




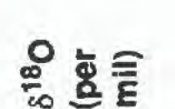

勇点言

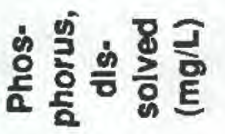

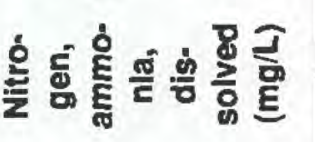

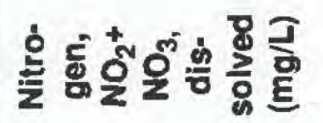

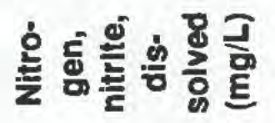

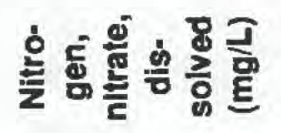

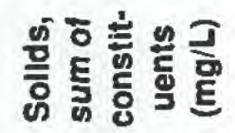

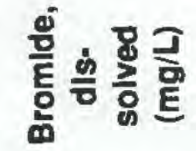

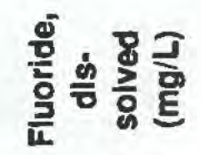

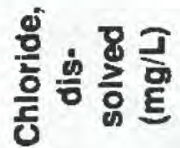

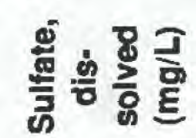

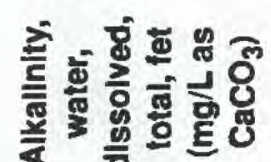

E

苋

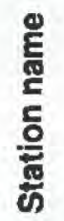

을

:

茂

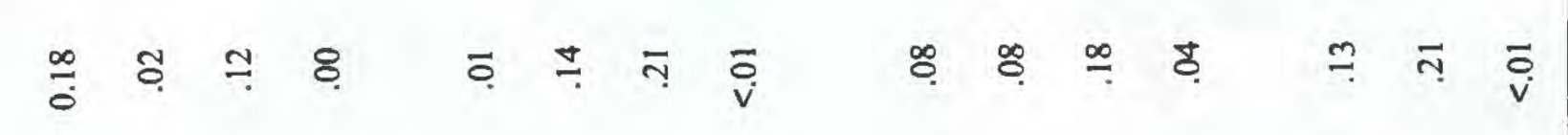

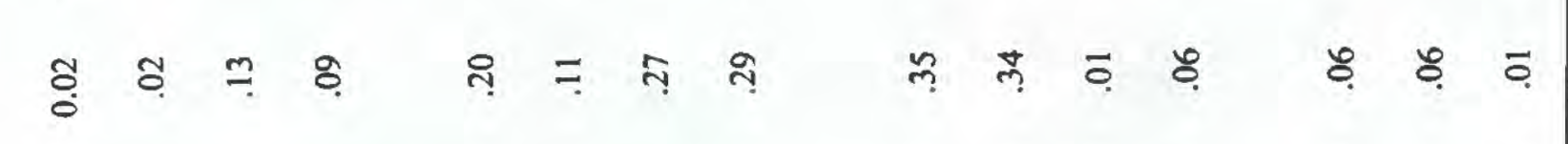

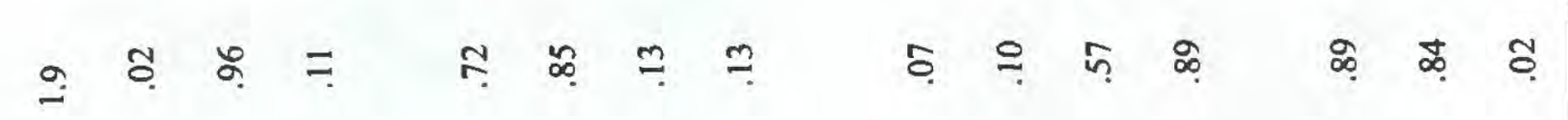

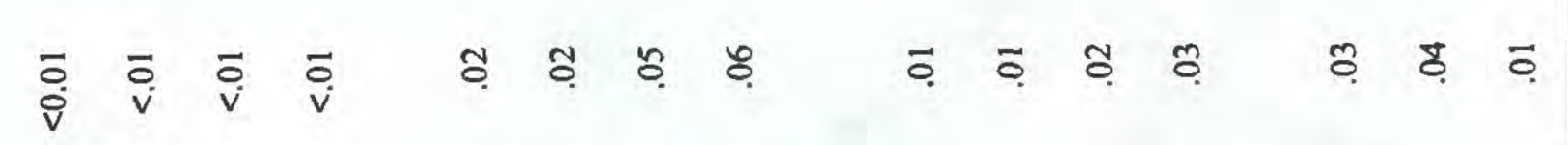

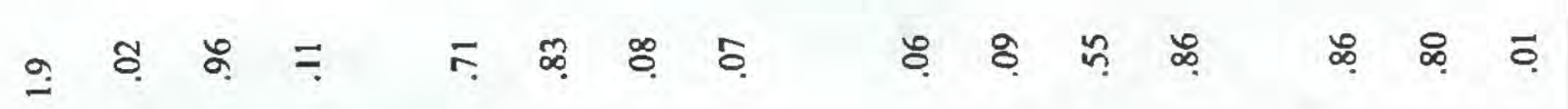

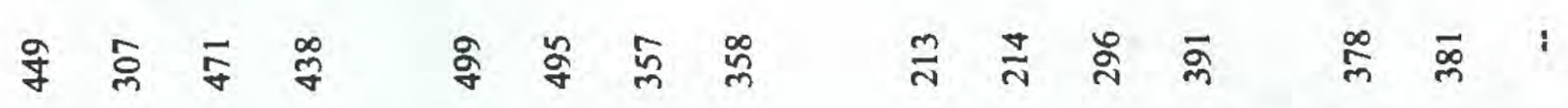

ஸุ

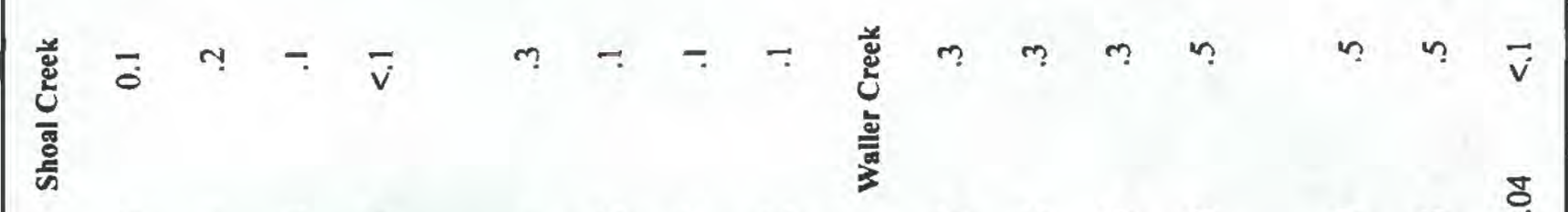

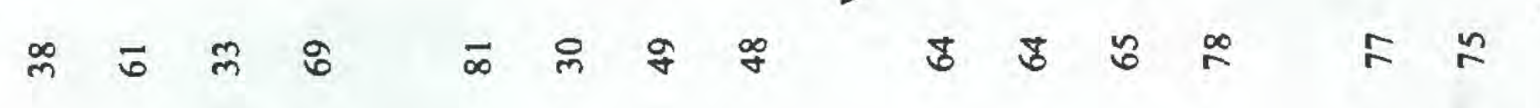

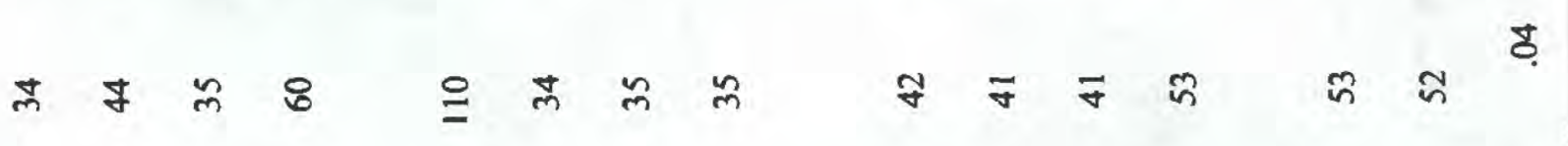

\&

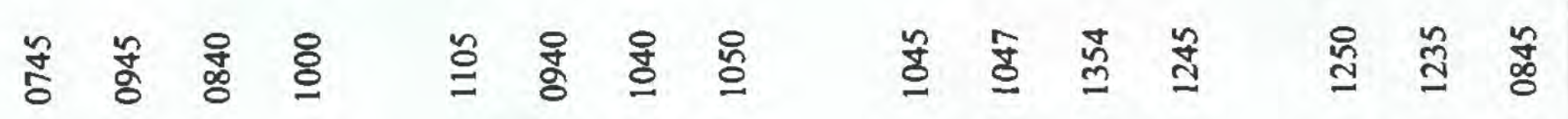

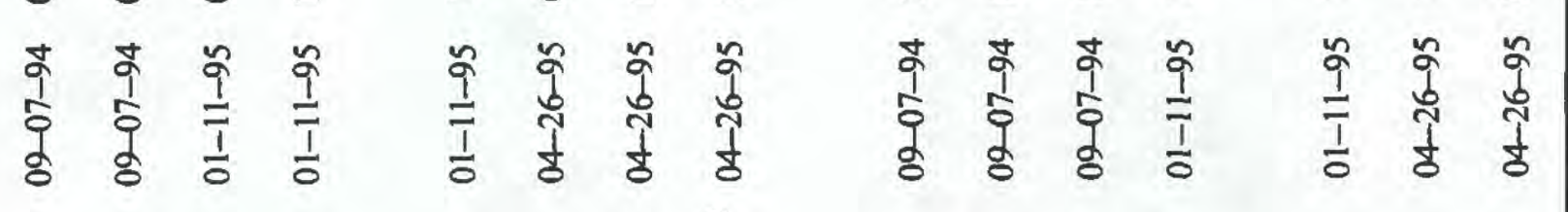

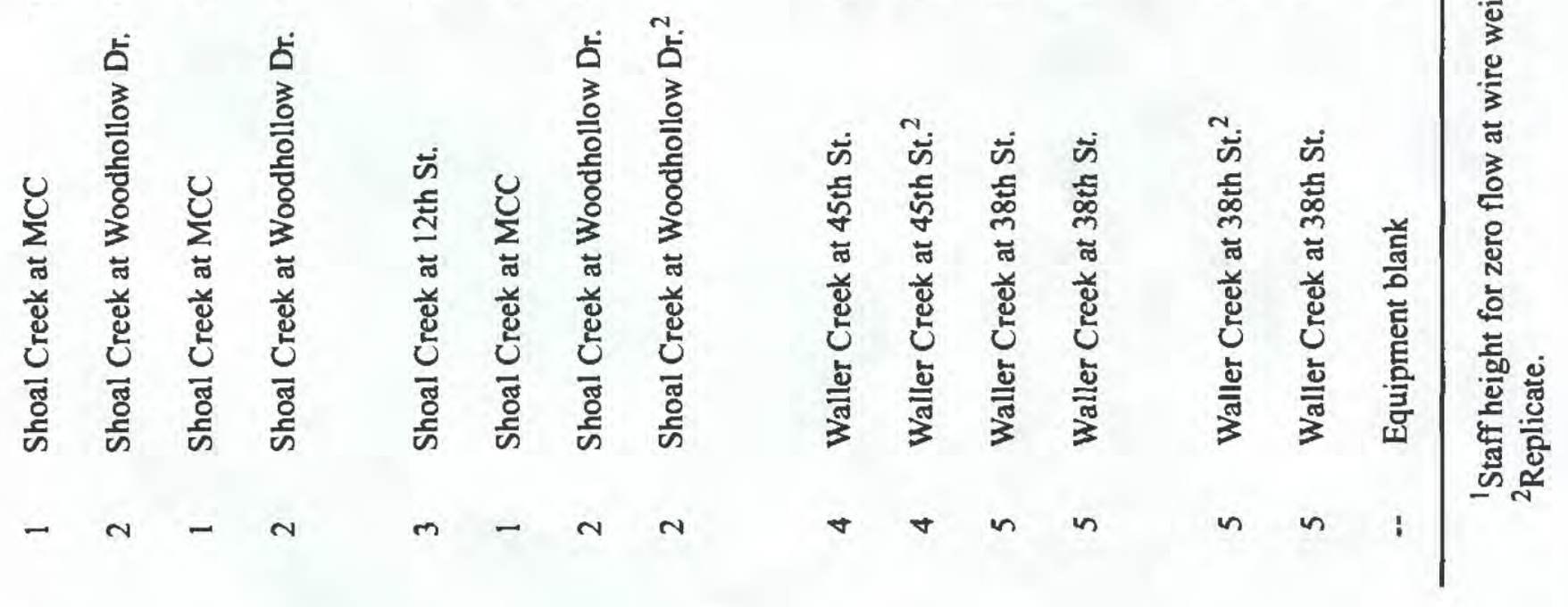

